\title{
The role of individual audit partners for narrative disclosures
}

\author{
Christoph Mauritz $^{1}$ (D) Martin Nienhaus $^{2}$ (D) $\cdot$ Christopher Oehler $^{2}$ (D)
}

Accepted: 26 July 2021 / Published online: 10 September 2021

(C) The Author(s) 2021

\begin{abstract}
We analyze the extent to which individual audit partners influence the audited narrative disclosures in their clients' financial reports. Using a sample of 3,281,423 private and public client firm-pairs, we find that the similarity among audited narrative disclosures is higher when two client firms share the same audit partner. Specifically, we find that the wording similarity of management reports (notes) increases by 30 (48) percent, the content similarity by 29 (49) percent, and the structure similarity by 48 (121) percent. Moreover, we find that audit partners in particular are relevant for their clients' narrative disclosures because the increase in narrative disclosure similarity when sharing the same audit partner is nine (four) times greater than when sharing the same audit firm (audit office). We show that this influence of audit partners goes beyond adding boilerplate statements and, using novel field evidence, we shed light on the underlying mechanisms. Our findings are economically relevant because a stronger involvement of audit partners with their clients' narratives is associated with a higher quality of narrative disclosures, which helps users better predict the future profitability of client firms.
\end{abstract}

Keywords Narrative disclosures - Audit partner style · Production of disclosures . Textual similarity

JEL Classification M38 · M42

\author{
Martin Nienhaus \\ nienhaus@wiwi.uni-frankfurt.de \\ Christoph Mauritz \\ christoph.mauritz@wiwi.uni-muenster.de \\ Christopher Oehler \\ oehler@wiwi.uni-frankfurt.de
}

1 University of Münster, Universitätsstr. 14-16, 48143 Münster, Germany

2 Goethe-University Frankfurt, Theodor-W.-Adorno-Platz 4. 14-16, 60629, Frankfurt am Main, Germany 


\section{Introduction}

Individual auditors play an important role in shaping their clients' financial reporting. Specifically, prior research has shown that two client firms that use the same audit firm produce more similar financial reports (Francis et al. 2014; DeFranco et al. 2020). However, the audit process largely builds on the personal interactions between the audit engagement partner and finance director (Beattie et al. 2004). Moreover, individual audit partners often have substantial discretion in interpreting and applying the in-house working rules of the audit firm or audit office. Hence, the personal characteristics of individual audit partners, such as risk aversion, expertise, cognitive ability, and preferences, can substantially affect the audit process (Nelson and Tan 2005). In this regard, Gul et al. (2013), Knechel et al. (2015), and Chen et al. (2020) find that individual audit partners influence their clients' earnings, accrual structure, and going-concern decisions. By contrast, we shed light on an unexplored side of the individual audit partner's influence on the financial reporting process: instead of earnings, accruals, or other quantitative financial statement items, we analyze the role of individual audit partners for audited narrative disclosures in the financial report.

Analyzing this role is important for at least two reasons. First, narrative disclosures provide incremental information to investors (e.g., Clarkson et al. 1999; Brown and Tucker 2011) and are relevant for predicting future returns (e.g., Bryan 1997; Barron et al. 1999; Francis et al. 2003; DeFranco et al. 2011b, Li et al. 2013). Therefore, enhancing our knowledge of the preparation process of narrative disclosures may be useful for valuation. Second, preparing and auditing narrative disclosures is fundamentally different from the quantitative parts of the financial report; thus, the way audit partners might influence narrative disclosures is arguably different. Particularly, narrative disclosures are less standardized, highly client-specific, partly forward-looking, and have less preparation and auditing guidance than quantitative financial statement items. Hence, auditors' personal characteristics (e.g., risk aversion, expertise, and cognitive abilities) are particularly important in compensating for this less structured and more informal audit approach. Moreover, this approach likely increases the need for auditor-client interactions during the audit of narrative disclosures. Furthermore, while a similar accrual or earnings structure may largely reflect the preference of an audit partner for a certain accounting or measurement method or degree of risk aversion (Francis et al. 2014), similarities in the wording or writing style of narrative disclosures are likely driven by a direct intervention of audit partners in their clients' financial reporting processes. Hence, additional research on the role of individual audit partners for narrative disclosures is necessary.

Additionally, focusing on narrative disclosures complements prior studies on the role of audit partners for their clients' financial reporting. Namely, our approach allows for the direct and easily observable extraction of an audit partner's style based on the client firms' narrative disclosures. We thereby avoid reliance on a model of the underlying accrual process. Moreover, while an audit partner's influence regarding earnings is likely limited to accrual choices that involve discretion, her influence on narrative disclosures is possible for any of the disclosures' elements and also along multiple dimensions, such as word choice, content, or structure. Furthermore, given that narrative disclosures are less standardized and have less preparation and audit guidance than earnings or accrual items (Beattie 2014), there is more room for audit partners to exert influence on narratives compared to the narrow valuation method 
or assumption choices in generally accepted accounting principles (GAAP). Finally, while accruals or earnings can be high or low for various reasons, a focus on textual design avoids any concerns about the direction of the influence. We thereby also avoid the possibility that audit partners' preferences for certain accounting methods or measurement choices ultimately offset each other's effects on earnings or accruals. Collectively, given our focus on narrative disclosures, we believe that we can better capture an audit partner's influence on clients' financial reporting.

To facilitate our empirical tests, we leverage a unique institutional setting. In Germany, many private and all public firms are mandated to publish annual financial reports. Apart from financial statements, these reports include mandatory management reports, which are comparable to the management discussion and analysis (MD\&A) and include narrative information such as a discussion of the firm's operations, an assessment of its future development, a discussion of its material risks and opportunities, and information on its financial and risk management. Unlike in the United States (US) and most European countries, the management report is subject to a mandatory full audit in Germany. ${ }^{1}$ Similarly, the notes, which detail the financial statement items, undergo a mandatory full audit. Hence, we have access to a unique dataset of audited narrative disclosures (i.e., management reports and notes) from a substantial number of private and public firms. Including private firms yields a sufficiently large number of client firm sharing audit partners. Another advantage of our setting is that audit partners must sign any audit opinions. This requirement has been in place for several decades and allows us to identify the individual audit partners and not just firms or offices. Hence, the German setting provides the unique opportunity to analyze the role of individual audit partners for narrative disclosures and serves as a starting point for research in the US context, once sufficient audit partner data are available there.

While it is the client firm managers' responsibility to write narrative disclosures, and audit partners' responsibility to determine whether these narrative disclosures comply with GAAP, the premise of our presumed mechanism for an audit partner's influence is that clients do not provide perfect first drafts. ${ }^{2}$ Given such imperfect drafts, audit partners can leverage their expertise, as they are primarily concerned with financial reporting, while client managers may have only a second-order interest in it. Based on audit partners' potentially superior expertise and because they eventually determine whether disclosures comply with GAAP, we posit that the interactions with clients along the audit process provide room for the audit partners to influence narrative disclosures.

\footnotetext{
${ }^{1}$ Since 1998, auditors in Germany must confirm with reasonable assurance that management reports reflect fairly the course of the business and a firm's future prospects. These strict audit requirements are also exceptional within the European Union, which has hitherto only introduced a mandatory review-not a full audit—of management reports in 2016. We provide additional background information on the German financial reporting environment in the Online Appendix. Particularly, we describe the general reporting and auditing requirements of private and public firms, the contents of management reports, and the specifics of providing assurance for narratives. Note that the Online Appendix also includes tables related to the additional analyses mentioned throughout the paper.

${ }^{2}$ Based on interviews with audit partners (described in detail below), this assumption seems plausible, especially for smaller client firms.
} 
To empirically test this influence, we compile a comprehensive set of measures to determine textual similarities based on computational linguistics. Specifically, we capture three dimensions of textual similarity: wording, content, and structure. To measure wording similarity, we employ the vector space model (e.g., Brown and Tucker 2011; Brown and Knechel 2016), which captures similarities in word choice and writing style. To measure content similarity, we use Latent Dirichlet Allocation (LDA) (Blei et al. 2003). This Bayesian machine learning approach identifies latent topics in a corpus of documents and the distribution of these topics in each document. Finally, we develop a measure for structure similarity based on section and subsection headings. Using these three measures allows us to comprehensively capture an audit partner's influence on clients' narrative disclosures and to differentiate between a solely wording-related influence and a more substantial influence related to contents or structure.

Using a sample of 3,281,423 client firm-pairs, we find that the degree of wording similarity of audited narrative disclosures increases by 30 percent (management report) and 48 percent (notes) when two client firms share the same audit partner. Similarly, topic similarity increases by 29 and 49 percent and structure similarity increases by 48 and 121 percent, respectively. These changes reflect an increase in the respective similarity measures of approximately 0.75 standard deviations. Furthermore, consistent with the notion that the audit partner in particular plays an important role for narrative disclosures, we find that when sharing the same audit partner, the increase is up to nine (four) times stronger than when sharing the same audit firm (audit office). We also show that the audit partner's influence is stronger for client firms with lower financial reporting expertise (small client firms) or incentives (private clients firms). Moreover, the effect is particularly pronounced for non-Big 4 auditors.

Further, to understand how audit partners exert this influence, we analyze whether they simply introduce standard text modules and boilerplate phrases or substantially influence new and unique contents that could be relevant for financial report users. We find that audit partners affect new text elements; thus, their influence is not limited to introducing standard text modules that do not change on an annual basis. We then complement these findings with an exploratory field study and conduct semi-structured interviews with audit partners. Combining these different data gathering approaches facilitates a broader understanding of how audit partners shape their clients' narrative disclosures (e.g., Bloomfield et al. 2016). The interviews support the notion that audit partners play an important role for the audit of narrative disclosures because these disclosures are largely their responsibility and not audit team members'. Moreover, auditors highlight that their clients' first versions of narrative disclosures are often poorly drafted, which is consistent with our premise of imperfect first drafts. Overall, we find evidence that audit partners exert a direct influence on their clients' narrative disclosures, and we document several mechanisms explaining this influence. For example, auditors ask clients to review financial reports written by other clients; or auditors, upon request, advise their clients about relevant topics to include in the narrative part of the financial report and provide relevant terms and phrases to mitigate litigation risk and foster GAAP compliance. To signal careful and 
thorough work to their clients, some auditors blue-pencil the report. Additionally, some clients directly ask auditors to help them with the report preparation.

Next, we demonstrate the economic relevance of our findings for the users of financial reports by shedding light on the consequences of audit partner-induced similarities. Specifically, we find that sharing an audit partner is related to an increase in comparability but not uniformity (i.e., interchangeable phrases with identical wording). Additionally, our results show that audit partner-induced similarities are related to properties of narrative disclosures that reflect higher disclosure quality, such as a lower degree of redundant information, fewer misspellings, and a higher degree of forward-looking information. Moreover, we find that the sentiment in forward-looking statements better predicts future profitability, indicating that narrative disclosures are more consistent with client firms' economic reality. These results suggest that audit partners who are more strongly involved in their clients' narrative disclosures tend to improve the quality of these disclosures, which may help users better predict the future profitability of client firms.

Finally, we provide additional analyses to test the robustness of our main results. Specifically, as a falsification test, we find that the effects of increased similarity when sharing an audit partner disappear for the narrative disclosures on client firms' websites, which are unaudited. Additionally, we use the instances of audit partner changes in our sample and find that a switch to a new audit partner increases the textual similarities with new common clients after the switch, and a switch to a different audit partner relatively decreases the textual similarities with former common clients. Finally, given the low percentage of client firm-pairs with the same audit partner and the concern that the large sample size may overestimate the t-statistics, we repeat our analyses based on a matched sample with a balanced number of client firm-pairs with and without the same audit partner. The results and inferences are similar.

To the best of our knowledge, our study is the first to show that individual audit partners influence their clients' narrative disclosures. We also show that this influence of audit partners on their clients' narratives is substantially more pronounced than that of audit offices or firms. This finding stresses the importance of considering audit partner effects beyond the audit firm or office. Furthermore, we identify situations in which the audit partners may be particularly likely to exert an influence, and we are the first to shed light on the mechanisms of these effects using field evidence. Finally, we show the positive consequences of auditors being highly involved in the preparation of narrative disclosures. We thereby answer the call for more research on auditor judgment at the individual partner level (DeFond and Francis 2005; Nelson and Tan 2005; Church et al. 2008; Francis 2011; Carcello and Li 2013).

We also add to the more general question of whether auditors shape their clients' financial reporting. This question has attracted considerable interest in the literature because financial reporting standards alone cannot explain reporting outcomes, as factors such as economic agents and institutional incentives also play important roles (e.g., Ball et al. 2003; Leuz et al. 2003). Similar to Gul et al. (2013) and Knechel et al. (2015), and Chen et al. (2020), we shed light on one important agent- the audit partner. However, our focus on narrative disclosures allows us to avoid the indirect capturing of an audit partner's influence on financial reporting decisions via an aggregated number, such as earnings or accruals. Moreover, the scope of the potential 
influence of auditors on narratives is wider and covers multiple dimensions compared with the narrow choices within GAAP, such as valuation methods or assumptions that affect accruals. Additionally, we use a client firm-pair approach with a tighter fixed effect structure than prior research, which eliminates concerns that the results are driven by firm-specific factors. Overall, we complement and extend the research on the role of auditors for financial reporting.

We also contribute to the literature on narrative disclosures, which are widely accepted as relevant to the users of financial statements and in predicting future returns. However, the research on the audit of narrative disclosures is scarce, and mostly focuses on the assurance of other predominantly narrative reporting instruments, such as CSR reports and forward-looking information in IPO prospectuses. As such, we lack evidence on the audit of management reports. At the same time, understanding the role of auditors in the context of narrative disclosures has recently gained international relevance because EU directive 2013/34/EU requires the assurance of management reports by auditors in all EU countries. Moreover, the International Auditing and Assurance Standards Board (IAASB) has recently documented an increased demand for more assurance of narrative disclosures from investors, analysts, accounting firms, and other professional bodies (IAASB 2018). Similarly, the Securities and Exchange Commission (SEC) and the Public Company Accounting Oversight Board (PCAOB) have discussed increasing auditor responsibility for narrative disclosures (SEC 2002; PCAOB 2004). Therefore, this study sheds light on the potential effects of more assurance for narrative disclosures and provides a starting point for future research in this area.

The remainder of this paper is structured as follows. Section 2 reviews prior literature, discusses our presumed mechanism, and provides empirical predictions. Section 3 describes the sample and data, Section 4 presents the results, and Section 5 concludes the paper.

\section{Background}

\subsection{Literature review}

Prior research suggests that auditors play an important role in shaping their clients' financial reporting. Most studies focus on the influence of audit firms and analyze the effects of audit firm characteristics, such as Big 4/non-Big 4 status (e.g., Becker et al. 1998), industry expertise (e.g., Reichelt and Wang 2010; Dunn and Mayhew 2004), and client importance (e.g., Reynolds and Francis 2000). However, little is known about the role of individual audit firms. In this regard, Francis et al. (2014) find that two clients sharing an audit firm have similar earnings and accrual structures and suggest that these increased similarities are indirectly driven by the audit firm's style, which comprises a unique set of audit firm-specific working rules for the implementation of auditing and accounting standards. Similarly, DeFranco et al. (2020) find that the unaudited MD\&As of a sample of public US firms are more similar when firms use the same audit firm or office, and McMullin (2016) finds that client firms borrow footnote language from geographic peers, industry peers, and audit firms. 
However, few studies focus on the role of individual audit partners, although the audit process largely builds on the personal interactions between the audit engagement partner and finance director (Beattie et al. 2004). ${ }^{3}$ Individual audit partners often have substantial discretion in interpreting and applying the in-house working rules of the audit firm or office. The studies on audit partners' role primarily use aggregated audit partner data and relate audit outcomes to partner characteristics such as tenure, client importance, specialization, partner gender, busyness, education, and social connections (Carey and Simnett 2006; Chen et al. 2008; Chen et al. 2010; Zerni 2012; Burke et al. 2019). Gul et al. (2013), Knechel et al. (2015), and Chen et al. (2020) use a similar approach to ours and focus on the effect of each individual audit partner. Their findings show that individual audit partners influence their clients' earnings, accrual structure, and going-concern decisions.

In contrast to these items or any other quantitative financial statement item, we focus on the narrative disclosures in the financial report. The reason for this is that the process of reporting and auditing narrative disclosures differs significantly from the quantitative parts of financial reports. Narrative disclosures are less standardized, highly client-specific, and partly forward-looking, and have less preparation and auditing guidance. Therefore, audit partner characteristics, such as risk aversion, expertise, and cognitive abilities, become particularly important in compensating for this less structured audit approach. As such, more room exists for an audit partner to leave a personal imprint. Moreover, the more flexible preparation and audit process requires more interactions and negotiations between audit partners and their clients. Hence, the audit partner characteristics that affect the auditor-client relationshipsand, ultimately, the auditor-client negotiations - could play a more important role for narrative disclosures than for the quantitative parts of financial reports. By contrast, while similarities in the quantitative parts of financial reports may largely reflect the preference of an audit partner for a certain accounting or measurement method or the degree of risk aversion (Francis et al. 2014), similarities in the wording or writing style of narrative disclosures may require a more direct intervention by audit partners in clients' financial reporting processes. Consequently, the findings of Gul et al. (2013), Knechel et al. (2015), and Chen et al. (2020) are unlikely to extend to our context of narrative disclosures. Hence, we analyze the influence of individual audit partners on their clients' audited narrative disclosures.

Focusing on narrative disclosures has several additional advantages. By directly extracting an audit partner's style in terms of wording, choice of topics, and structure, we avoid reliance on an underlying model of the accrual process. Moreover, there is substantial room for audit partners to influence narrative disclosures, while an analysis of earnings is limited to the accrual choices that allow discretion. Additionally, narrative disclosures allow the analysis of different dimensions of a potential influence, such as word choice, content, or structures, whereas accruals or earnings can only be (abnormally) low or high. We also avoid the potential issue that audit

\footnotetext{
${ }^{3}$ Data limitations are likely the reason for the focus on audit firms, because many countries do not require the disclosure of individual audit partners. For example, in the US, the PCAOB only requires the filings of individual audit engagement partner names since 2017 (PCAOB 2015). Consequently, most research on audit partners focuses on non-US settings.
} 
partners' preferences for specific accounting methods or measurement choices may offset each other in their effects on accruals and that accruals reverse. Overall, given our focus on narrative disclosures, we believe we can better capture an audit partner's influence on clients' financial reporting.

\subsection{Presumed mechanism and empirical predictions}

The premise of the presumed mechanism of an audit partner's influence is that clients deliver an imperfect first draft of the financial report to their audit partner. On one hand, client firm managers may deliberately deliver an imperfect draft, with the expectation that the audit partner will assist them in preparing GAAPcompliant disclosures. On the other hand, client managers might lack sufficient expertise to produce GAAP-compliant narrative disclosures. This situation resembles a disclosure-production decision by client firm managers, who can either produce GAAP-compliant disclosures in-house or outsource some of the production to their auditor. $^{4}$

To structure our argument, we use the notion of a production function of disclosures from the perspective of the client firm and assess the relative production costs for both client firms and audit partners, where the production costs of audit partners are ultimately passed on to the client firms via billed fees. Hence, the production decision (i.e., the allocation between in-house production and outsourcing) depends on the marginal costs of in-house production and the costs charged by the audit partners for their services. The production costs of both parties are influenced by several factors. For example, client firm managers are primarily concerned with business decisions other than financial reporting. By contrast, audit partners are concerned with financial reporting compliance. As such, audit partners may have more financial reporting expertise, resulting in lower production costs. Moreover, audit partners can spread the costs of gaining this expertise over their entire client base, and this scaling effect reduces their marginal production costs. Therefore, audit partners' relative production costs may be lower, especially compared to those clients that have relatively little financial reporting expertise. Additionally, audit partners ultimately determine whether clients' narrative disclosures comply with GAAP, and could thus be more efficient in producing the "right" disclosure level. Lastly, audit partners might perceive utility from maintaining or improving their relationship with clients, which again affects the price of outsourcing.

However, even if the direct production costs are lower for audit partners, outsourcing some of the production to audit partners could be restricted by other factors,

\footnotetext{
${ }^{4}$ This case is similar to a standard production function model, which allows production subcontracting (e.g., López 2014). For simplicity, we assume that client firms simply aim to produce GAAP-compliant disclosures. However, it is also possible that client firms aim to produce GAAP-compliant and particularly high-quality disclosures. Alternatively, some client firms may want GAAP-compliant disclosures that reveal a minimum amount of proprietary information that may be useful for competitors. The general structure of our discussion would be similar in all of these cases, but the relative production costs may slightly differ. For example, it might be cheaper for client firms to produce high-quality disclosures if such disclosures are particularly client firm-specific, where audit partners lack knowledge.
} 
resulting in additional production costs. Many audit firms attempt to restrict the influence of individual audit partners through quality control mechanisms. For example, mechanisms such as the standardization of work procedures, centralized control of key decisions, internal reviews, second partner sign-offs, and technical consultations mitigate individual audit partner idiosyncrasies (e.g., Jeppesen 2007; Bedard et al. 2008; Jenkins et al. 2008; Bell et al. 2015). Hence, circumventing the quality control mechanisms of audit firms may lead to additional costs for audit partners. Moreover, while similar accrual or earnings structures may largely reflect the preference of an auditor for a certain accounting or measurement method (Francis et al. 2014), similarities in the wording or writing style of narrative disclosures may require a more direct intervention by auditors in their clients' financial reporting processes. However, the direct involvement of audit partners in the preparation of the contents they are supposed to audit would contrast with the ethical requirements of the International Standards on Auditing (ISA). Specifically, self-reviews, which include the performance of services for a client that directly affect the subject matter of the assurance engagement, violate the ethics code for auditors, according to the ISA. ${ }^{5}$ As increased textual similarities can be driven by "co-creation," auditors should be incentivized to not exert direct influence on their clients' preparation processes. Hence, production costs could be high because of the resulting litigation risk, and managers may shift the production in-house. Additionally, some client firms may aim to produce highquality disclosures that go beyond simple GAAP-compliance. In these cases, it may be cheaper for client firms to produce such disclosures in-house if the disclosures are particularly firm specific.

The marginal production costs might also be shaped by psychological aspects. The psychological literature shows that human beings innately desire to leave their mark. Specifically, fundamental human needs theory suggests that participation in terms of expressing opinions and taking actions is ontological, that is, intrinsically tied to being human (Max-Neef 1991). Moreover, social psychology explores a number of superiority biases indicating that people are convinced of themselves and their opinions (Hoorens 1993) and are prone to advise with economic or social benefits in mind or just for inner self-reward and joy (Guy and Patton 1988). Consequently, when audit partners interact with clients during the preparation of narrative disclosures, these innate desires could drive them to affect wording, contents, and structure. Audit partners may factor this utility into the price of outsourcing, which would render outsourcing cheaper.

Overall, the extent to which audit partners affect their clients' preparation of narrative disclosures depends on the relative production costs of these disclosures. ${ }^{6}$ Given

\footnotetext{
${ }^{5}$ See ISA.200.A14 and IESBA Code 200.5.

${ }^{6}$ Note that this general mechanism also applies to settings with lower or no audit requirements for narrative disclosures. Lower levels of assurance provide client firms with more discretion about the quality of narrative disclosures. Moreover, audit partners may be less demanding, which ultimately affects in-house and outsourcing production costs. The basic trade-off between in-house production and outsourcing, however, remains the same. For example, while lower audit requirements will largely mitigate audit partners' incentives to increase the quality of client firms' narrative disclosures, they will also make outsourcing cheaper, given that auditors face a lower level of litigation risk. This could affect the in-house-outsourcing trade-off in an ambiguous way.
} 
that different cost arguments exist, as elaborated above, audit partners' influence on clients' narrative disclosures is ultimately an empirical question.

\section{Sample and data}

We select all observations of German firms on DAFNE, which is a Bureau van Dijk database of private and public client firms. ${ }^{7}$ Our sample period starts from 2007 because annual reports are not reliably available prior to that. Moreover, we do not include client firm-years after 2012 because of a change in the German management reporting requirements in $2013 .{ }^{8}$ We include all private and public client firms in the initial sample (146,190 firm-years). ${ }^{9}$ The small client firms that do not meet the bright-line size threshold for mandatory audits are eliminated $(17,243$ firm-years). ${ }^{10}$ Because we manually collect annual reports from the German federal gazette (www.bundesanzeiger.de), we draw a random subsample of 11,306 client firm-years from the remaining firm pool.

Next, we automatically parse the management reports, notes, auditor identities, ${ }^{11}$ and textual characteristics from the annual report. After dropping the observations when the parsing of narrative disclosures fails ${ }^{12}$ and when financial or auditor data are not available, we obtain a final sample of 6,238 firm-years and 1,672 individual auditors. In contrast to the style fixed effects literature (e.g., Bertrand and Schoar 2003; Ge et al. 2011; Francis et al. 2014), we run all empirical tests based on client firm-pairs. The advantage of this approach over the style fixed effects approach at the client firm-year level is that it avoids the issue of misspecified F-tests (Fee et al. 2013). Moreover, the client firm-pair approach allows us to specify different dimensions of similarity we could not use at the client firm-year level, which provides us with a more granular view of how auditors shape their clients' narratives. Furthermore, using the client firm-pair approach, we can determine the magnitude of the changes in similarity, which is not possible under the style fixed effects approach. Matching each client firm with all other client firms within each sample

\footnotetext{
${ }^{7}$ We require private client firms to prepare their annual accounts according to German GAAP to eliminate voluntary International Financial Reporting Standards (IFRS) adopters, because these firms may have different reporting incentives.

${ }^{8}$ German Accounting Standard 20 (GAS 20) changed management reporting practice, especially the structure of management reports in Germany. Hence, we decided not to include these observations.

${ }^{9} \mathrm{We}$ consider single companies as well as groups. For groups, we only include client firms that are global parent companies to avoid matching parent companies with their subsidiaries.

${ }^{10}$ Under German law, firms are classified as small, medium, or large. This classification determines disclosure and auditing requirements. For instance, as small firms are exempt from both mandatory audits and the preparation of management reports, we exclude them from our sample. Similarly, we do not consider non-limited liability firms because they are generally not required to provide public disclosures. Firms without available data for the determination of the bright-line size threshold are excluded from the sample.

${ }^{11}$ We manually complement and correct auditor data where the parsing algorithm fails. We also normalize audit firm and office data when different names obviously refer to the same firm or office.

${ }^{12}$ We drop the observations with narrative disclosures below 100 words. Reviewing some of these observations suggests that our parsing algorithm did not work correctly in such cases.
} 
year and dropping observations with similarity values above the 99th percentile for all similarity proxies ${ }^{13}$ yields a final sample of 3,281,423 client firm-pairs.

\subsection{Measuring textual similarity}

We compile a comprehensive set of measures to determine the similarities between two documents. Using computational linguistics, we capture textual similarities along three dimensions: wording, content, and structure. We conjecture that these three dimensions reflect the different avenues of an audit partner's influence. For example, wording similarity captures the more direct influence of blue-penciling reports or intervening in the writing. Content similarity, by contrast, is less direct and may rather reflect general advice about what topics to include. Finally, the provision of templates or the preference for a certain structure may lead to structure similarity.

Note that annual reports contain two main narrative elements: management report and notes. While the notes detail financial statement items, the management report provides the management's assessment of the current situation and a discussion of probable future developments. In this regard, the management report provides more degrees of freedom than the notes. However, the notes are generally more technical and more closely related to accounting requirements. In our empirical analyses, we use separate tests for the two elements. This approach allows us to identify potential differences in the audit partner's influence resulting from the conceptual differences of the two narrative elements.

\subsubsection{Wording similarity}

To measure wording similarity, we follow the literature and employ the vector space model (Salton et al. 1975). This model transforms each document into an $n$ dimensional term frequency vector, and the similarity between two documents is represented by the cosine of the angle between the corresponding vectors. ${ }^{14}$

To compute the wording similarity measure, we first construct a lexicon that contains all words in all documents in our sample. We strip all punctuation, special characters, and numbers from the words. Furthermore, we stem all words using the snowball stemming algorithm to reduce computing time and focus on word choice according to Brown and Tucker (2011). Additionally, we ignore stop words because they are very common and do not contain relevant information. Next, we construct a term frequency vector for every client firm-year. Following the literature (Brown and Tucker 2011; Brown and Knechel 2016), we employ inverse document frequency

\footnotetext{
${ }^{13}$ Manually reviewing the highest-similarity pairs reveals that most of these pairs reflect two data collection errors. First, the same annual report has accidentally been downloaded and stored for two different firms. Second, in some instances, the request from DAFNE to include only global parent companies did not work, leading to affiliated firm-pairs.

${ }^{14}$ For examples of the mechanics of the vector space model, see Brown and Tucker (2011) or Appendix B of Brown and Knechel (2016).
} 
(IDF) weighting to all term frequency vectors, which involves weighting every word in the lexicon by the logarithm of $M / m$, where $M$ is the number of documents in the sample and $m$ is the number of documents in which the weighted word appears. This approach reduces the weight of common words and puts significantly more weight on words that are uncommon or unique. The higher weighting of uncommon words better reflects the writing style in terms of vocabulary preference.

Based on the term frequency-IDF vectors for each client firm-year, we calculate the pairwise similarities of narrative disclosures for all possible client firm-pairs in each year and obtain a wording similarity score WORDING_SIM $M_{i, j}$. This is a continuous variable that ranges from 0 to 1 , with higher values representing greater similarity. ${ }^{15}$

\subsubsection{Content similarity}

To measure content similarity, we use the LDA, as proposed by Blei et al. (2003). LDA is an unsupervised machine-learning approach that identifies a predefined number of latent topics in a corpus of documents. LDA assumes that documents are represented as distributions over the latent topics, whereas topics are distributions over words.

Applying LDA to our corpus of documents yields a topic distribution for each document and a word distribution for each topic. Hence, compared to the vectorspace representation of wording, where each vector has the length of all unique words in the corpus, LDA reduces each document to a vector of the length of the number of predefined topics $K$, where the $k$-th element in the document-vector represents the share of the $k$-th topic in the document.

Because the number of topics must be set as a parameter of the LDA, the optimal number of topics is unclear ex ante. As such, we train multiple LDA models for different numbers of topics ${ }^{16}$ and compute the perplexity of a 10 percent hold-out sample to determine the optimal number of topics (Blei et al. 2003). A lower perplexity value indicates better generalization performance. Based on the perplexity values, ${ }^{17}$ we set the number of topics to 30 in the corpus of management reports, and 20 in the notes corpus. Examples of topics in the management report are corporate governance (top five words: supervisory board, stock, remuneration, member, general meeting), operations (top five words: order inflow, machine, manufacturing, research, unfilled orders), strategy (top five words: sustainable, strategy, safe, challenges, success), and industry-specific topics such as agriculture (top five words: agriculture,

\footnotetext{
${ }^{15}$ To interpret WORDING_SIM ${ }_{i, j}$ as percentage, we multiply WORDING_SIM $i, j$ and the other two proxies by 100 . Additionally, we provide examples from actual management reports in our sample with differenct levels of WORDING_SIM $M_{i, j}$ in Table 11 in the Appendix.

${ }^{16} \mathrm{We}$ apply the following preprocessing steps to the corpus before training the models: in addition to the preprocessing to calculate wording similarity, we follow Dyer et al. (2017) and (1) remove words that do not appear in at least 100 documents, (2) are in the top 0.1 percent of the most common words, or (3) appear in every document. After these eliminations, we only retain documents with more than 100 words because LDA does not perform well on very short documents.

${ }^{17}$ For an overview of the perplexity, see the Online Appendix.
} 
milk, fiscal-year, price, EU). ${ }^{18}$ Based on the topic vectors for all documents, we calculate CONTENT_SIM ${ }_{i, j}$ as the cosine similarity between two client firms' document topic vectors. Higher values imply more similar documents in terms of content.

\subsubsection{Structure similarity}

To measure structure similarity, we develop a measure based on the headlines of sections and subsections. Specifically, we parse the headlines of each document and compute similarity based on the cosine similarity measure. Each headline vector contains the exact headline — as an element—which may consist of multiple words in a specific order. We do not perform any preprocessing such as word stemming or removing stop words. We thereby consider the numeration style of subsections, such as Roman numerals, Arabic numerals, or alphabetical. Hence, STRUCTURE_SIM $i, j$ captures the similarities of exact headline matches, which may stem from using specific templates. ${ }^{19}$

\subsection{Model and independent variables}

Our general model at the client firm-pair level is as follows:

$$
\begin{aligned}
\text { SIMILARITY }_{i, j, t}= & \left.\alpha+\beta_{1} \text { SAME_AUDITOR }_{\text {Partner }}\right)_{i, j, t}+\Sigma \beta_{k} \text { Controls }_{i, j, t} \\
& +\Sigma \beta_{l} \text { Client firm }_{i} \times \text { Year }_{t} F E+\Sigma \beta_{m} \text { Client firm }_{j} \\
& \times \text { Year }_{t} F E+\varepsilon_{i, j, t}
\end{aligned}
$$

The main independent variable of interest is SAME_AUDITOR(Partner $)_{i, j}$, which is an indicator variable that equals one if two client firms $i$ and $j$ share an audit partner, and zero otherwise. ${ }^{20}$ To control for other factors that may drive the textual similarities between two client firms, we include several client firm-pair control variables. Client firms that operate in the same industry are likely to be exposed to a

\footnotetext{
${ }^{18}$ For an overview of all topics in the management reports and notes, including the top five words, refer to the Online Appendix. One potential drawback of the LDA algorithm is its tendency to provide topic distributions that are skewed towards one topic. To alleviate the concern that our results are driven by this "bias," we examine the topic distributions in our corpus. This analysis shows that the average share of the most (second most, third most) prevalent topic in the management reports is $17.9(14.3,11.2)$ percent, indicating that the topic distributions are not highly skewed towards a single topic. An analysis of the notes corpus yields similar results.

${ }^{19}$ While classification as a match is relatively conservative under this approach, the results are similar, albeit stronger, when we run the same test on a word-element basis instead of a headline-element basis. Note that the exact headlines or sections are not prescribed by German GAAP.

${ }^{20}$ In some cases, two audit partners sign the audit opinion. In our main specification, we define two client firms as having the same audit partner when at least one audit partner is the same. In robustness tests, the results are similar, albeit slightly weaker in magnitude, for client firm-pairs with two signing audit partners. This finding is plausible because two partners might dilute the effect of each individual partner, which is consistent with the notion that second partner signoffs are a tool for mitigating individual partner idiosyncrasies. Moreover, as another robustness test, we require that the first signing audit partner match for a client firm-pair to be considered to have the same auditor. The first signing audit partner is generally the one who conducts the actual on-site audit procedures. Based on this definition, the results are significantly stronger.
} 
similar economic environment, which should increase the similarity of their narrative disclosures. Hence, we include SAMEINDUSTRY $Y_{i, j}$, which is an indicator variable equal to one if both client firms $i$ and $j$ share the same two-digit SIC industry code, and zero otherwise. ${ }^{21}$ McMullin (2016) finds that firms tend to borrow footnote boilerplate text from regional peers. Therefore, we control for $S A M E \_R E G I O N_{i, j}$, which is an indicator variable equal to one if client firms $i$ and $j$ are based in the same region, and zero otherwise. ${ }^{22}$ Moreover, we control for SAME_ACCOUNTS ${ }_{i, j}$, which is an indicator variable equal to one if both client firms prepare their annual report either on a single entity or on a consolidated basis, and zero otherwise. We also control for the similarity of the economic characteristics of each client firm-pair: size, return on assets, leverage, and revenue growth. SIZE_SIMILARITY ${ }_{i, j}$ is the absolute difference in the logarithm of total assets between the two client firms multiplied by -1 , so that higher values represent greater economic similarity. ROA_SIMILARITY ${ }_{i, j}$, GROWTH_SIMILARITY $_{i, j}$, and LEVERAGE_SIMILARITY ${ }_{i, j}$ are calculated as the absolute differences in $R O A$, revenue growth, and leverage, multiplied by -1 , respectively. We also include $L E N G T H_{-}$SIMILARITY $Y_{i, j}$ as the absolute difference in the length of both documents, multiplied by -1 . The continuous similarity variables are all winsorized at the first percentile. To control for the listing status of client firms $i$ and $j$, we include SAME_PUBLIC_PRIVATE $E_{i, j}$, which equals one if client firms $i$ and $j$ are both either private or publicly listed, and zero otherwise.

We further include client firm $i$-by year and client firm $j$-by year fixed effects. Under this approach, we do not need client firm $i$ - or client firm $j$-level control variables because our fixed effects absorb any client firm-year specific factors. ${ }^{23}$ Hence, our identification solely stems from the variation between client firm-pairs, and any yearly firm-specific factors are controlled for. ${ }^{24}$ We use two-way clustered standard errors on client firm $i$ 's and $j$ 's audit partners. ${ }^{25}$ Table 1 presents the descriptive statistics of all variables.

\footnotetext{
${ }^{21}$ While our primary measure of SAME_INDUSTRY $Y_{i, j}$ only considers the main industry that a company operates in, we alternatively measure $S A M E_{I} I N D U S T R Y_{i, j}$ based on any overlap between all two-digit SIC industries of client firms $i$ and $j$. This approach considers conglomerates with partially similar business activities. The inferences remain unchanged.

${ }^{22}$ The first two digits of the German ZIP code represent the region. Alternatively, we define DISTANCE $_{i, j}$ as the direct distance between the headquarters of client firms $i$ and $j$, multiplied by -1 . This measure is more precise for measuring the geographical distance between two client firms. Using this alternative measure or different order polynomials of this measure does not change our inferences.

${ }^{23}$ Brown and Tucker (2011) show that the similarity score under the vector space model mechanically increases with the length of documents. This is because the larger a document is, the more likely it is to contain the same words as the document it is compared with. Our fixed effects structure also eliminates any effects that stem from the length of client firms $i$ 's or $j$ 's documents.

${ }^{24}$ Prior studies with firm-pair designs largely rely on year fixed effects and within-industry pairing (e.g., Francis et al. 2014; Chen et al. 2020). While our fixed effects structure is tighter than industry and year absorption, we replicate our analyses using within industry-year pairing at the two-digit SIC level and industry and year fixed effects (see the Online Appendix for details). The results and inferences are similar. Notably, the effect size and significance are stronger in our main specification.

${ }^{25}$ This approach yields approximately $2 \times 1,600$ clusters for each model. The results and inferences remain similar when we cluster at the two-digit SIC level, client firm-pair level, or for the two-way clustering at client firms $i$ and $j$.
} 
Table 1 Descriptive statistics

\begin{tabular}{|c|c|c|c|c|c|c|}
\hline & $\mathrm{N}$ & Mean & STD & Q1 & Median & Q3 \\
\hline \multicolumn{7}{|l|}{ Main independent variables } \\
\hline SAME_AUDITOR(Partner $)_{i, j}$ & $3,281,423$ & 0.001 & 0.030 & 0.000 & 0.000 & 0.000 \\
\hline SAME_AUDITOR(Office $)_{i, j}$ & $3,281,423$ & 0.002 & 0.048 & 0.000 & 0.000 & 0.000 \\
\hline SAME_AUDITOR(Firm) $)_{i, j}$ & $3,281,423$ & 0.018 & 0.133 & 0.000 & 0.000 & 0.000 \\
\hline \multicolumn{7}{|l|}{ Dependent variables } \\
\hline \multicolumn{7}{|l|}{ Management report } \\
\hline WORDING_SIM ${ }_{\mathrm{i}, \mathrm{j}}$ & $3,281,423$ & 5.007 & 3.202 & 3.102 & 4.303 & 5.956 \\
\hline CONTENT_SIM ${ }_{i, j}$ & $3,165,995$ & 41.575 & 20.684 & 25.202 & 40.403 & 56.923 \\
\hline STRUCTURE_SIM $_{i, j}$ & $3,281,423$ & 2.577 & 11.988 & 0.000 & 0.000 & 0.000 \\
\hline \multicolumn{7}{|l|}{ Notes } \\
\hline WORDING_SIM ${ }_{\mathrm{i}, \mathrm{j}}$ & $3,126,216$ & 6.351 & 4.287 & 3.699 & 5.256 & 7.572 \\
\hline CONTENT_SIM ${ }_{\mathrm{i}, \mathrm{j}}$ & $3,093,744$ & 46.496 & 28.016 & 22.485 & 48.697 & 69.221 \\
\hline STRUCTURE_SIM $_{i, j}$ & $3,086,504$ & 2.381 & 9.286 & 0.000 & 0.000 & 0.000 \\
\hline \multicolumn{7}{|l|}{ Control variables } \\
\hline SAME_INDUSTRY $_{i, j}$ & $3,281,423$ & 0.105 & 0.307 & 0.000 & 0.000 & 0.000 \\
\hline SAME_REGION ${ }_{i, j}$ & $3,281,423$ & 0.019 & 0.135 & 0.000 & 0.000 & 0.000 \\
\hline SAME_ACCOUNTS $_{\mathrm{i}, \mathrm{j}}$ & $3,281,423$ & 0.556 & 0.497 & 0.000 & 1.000 & 1.000 \\
\hline SIZE_SIMILARITY $_{\mathrm{i}, \mathrm{j}}$ & $3,281,423$ & -1.438 & 1.065 & -2.101 & -1.225 & -0.570 \\
\hline ROA_SIMILARITY $_{i, j}$ & $3,281,423$ & -8.883 & 8.666 & -11.870 & -6.390 & -2.880 \\
\hline GROWTH_SIMILARITY $_{i, j}$ & $3,281,423$ & -19.189 & 21.751 & -24.552 & -12.512 & -5.537 \\
\hline LEVERAGE_SIMILARITY $_{i, j}$ & $3,281,423$ & -5.829 & 18.209 & -3.590 & -1.560 & -0.640 \\
\hline SAME_PUBLIC_PRIVATE $\mathrm{i}_{\mathrm{i}, \mathrm{j}}$ & $3,281,423$ & 0.816 & 0.387 & 1.000 & 1.000 & 1.000 \\
\hline
\end{tabular}

This table presents descriptive statistics for the dependent and independent variables. SAMEAUDITOR $(\text { Partner })_{i, j}$ is an indicator variable that equals one if client firms $i$ and $j$ share the same audit partner in a year, and zero otherwise. SAME_AUDITOR $(\text { Office })_{i, j}$ is an indicator variable that equals one if client firms $i$ and $j$ share the same audit office in a year but not the same audit partner, and zero otherwise. SAME_AUDITOR(Firm $)_{i, j}$ is an indicator variable that equals one if client firms $i$ and $j$ share the same audit firm in a year but not the same audit office or partner, and zero otherwise. WORD$I N G_{-} S_{I M} M_{i, j}$ is the cosine of the angle between the IDF-weighted term frequency vectors of management reports or notes $i$ and $j$, multiplied by 100 . CONTENT_SIM ${ }_{i, j}$ is the cosine of the angle between the topic vectors of management reports or notes $i$ and $j$, multiplied by 100. STRUCTURE_SIM $i, j$ is the cosine of the angle between the headline vectors, which contain the exact headings of management reports or notes $i$ and $j$, multiplied by 100. SAME_INDUSTRY $Y_{i, j}$ is an indicator variable that equals one if client firms $i$ and $j$ share the same two-digit SIC industry code, and zero otherwise. SAME_REGION ${ }_{i, j}$ is an indicator variable that equals one if client firms $i$ and $j$ are based in the same region, and zero otherwise. $S A M E \_$ACOUNTS $S_{i, j}$ is an indicator variable that equals one if both client firms $i$ and $j$ prepare their annual report either on a single entity or on a consolidated basis, and zero otherwise. SIZE_SIMILARITY $i, j$ is the absolute difference in the logarithm of total assets of client firms $i$ and $j$, multiplied by minus one. ROA_SIMILARITY ${ }_{i, j}$ (GROWTH_SIMILARITY ${ }_{i, j}$, LEVERAGE_SIMILARITY $_{i, j}$ ) is the absolute difference in $R O A$ (revenue growth measured as the change in total sales from year t- 1 to t, scaled by total sales in $\mathrm{t}-1$; leverage measured as total debt scaled by total assets) of client firms $i$ and $j$, multiplied by minus one. SAME_PUBLIC_PRIVATE $i, j$ is an indicator variable that equals one if client firms $i$ and $j$ are either both public or private, and zero otherwise 
Of our 3,281,423 client firm-pairs, 2,961 (0.01 percent) are audited by the same audit partner. Moreover, 7,692 (0.2 percent) are audited by the same audit office but not the same audit partner, and 58,800 (1.8 percent) are audited by the same audit firm but not the same audit office or partner. Approximately 9 percent of the client firmpairs are from the same industry, and 2 percent are from the same region. Untabulated descriptive statistics at the client-firm level show that 26.1 percent of all firm-years are audited by a Big 4 auditor. Approximately 10 percent of all firm-years are from public firms, and the mean firm has 1,280 employees. $^{26}$

\section{Empirical results}

\subsection{Main results}

Table 2 presents the main results. In all regressions, we use a log-linear specification to allow the percentage change interpretation of the coefficients. Specifically, we use the natural logarithm of our dependent variables plus 1 and regress them on SAME_AUDITOR(Partner $)_{i, j}$ and the control variables. ${ }^{27}$

Column 1 of Panel A in Table 2 presents the results for wording similarity based on management reports. The coefficient on our main variable of interest, SAME_AUDITOR(Partner $)_{i, j}$, is 26.35 and significant at the 1 percent level. This coefficient means that sharing an audit partner is associated with a higher degree of wording similarity between two client firms' management reports by approximately 30 percent. $^{28}$ Column 2 shows that content similarity increases by 29 percent; in Column 3 , we find that structure similarity increases by 48 percent.

Consistent with our expectations, the coefficients on the control variables generally show that client firm-pairs are textually more similar when they are from the same region and industry. Likewise, textual similarity increases when client firm-pairs are more comparable in terms of size, profitability, leverage, and growth. Overall, Panel A of Table 2 supports the notion that sharing the same audit partner increases the textual similarity of management reports.

In Panel B of Table 2, we provide the same analyses for the notes. The results are qualitatively similar, albeit stronger in terms of statistical significance and economic magnitude. Specifically, wording similarity increases by 48 percent, content similarity by 49 percent, and structure similarity by 121 percent. $^{29}$ The finding that auditor-driven similarities are stronger for the notes than for the management reports is not surprising. Because the notes are more technical and more closely related to accounting requirements, audit partners may be able to provide better guidance for them, given their subject matter knowledge of accounting rules.

\footnotetext{
${ }^{26}$ See Table 12 in the Appendix for more descriptive statistics at the client-firm level.

${ }^{27}$ We multiply the natural logarithm of 1 plus the dependent variable by 100 to simplify the interpretation.

${ }^{28}$ To determine the percentage increase, we use the coefficient on SAME_AUDITOR(Partner $)_{i, j}$ and calculate $\exp (26.35 / 100)-1$.

${ }^{29}$ For both panels, this equates to an increase in similarity of $0.92(0.57,0.40)$ standard deviations for wording (content, structure) of the management report and $1.01(0.58,1.03)$ standard deviations for the notes.
} 
Table 2 The relation between sharing an audit partner and similarity in narrative disclosures

\begin{tabular}{|c|c|c|c|}
\hline & WORDING_SIM ${ }_{i, j}$ & CONTENT_SIM $\mathrm{i}_{\mathrm{j}}$ & STRUCTURE_SIM ${ }_{i, j}$ \\
\hline \multicolumn{4}{|l|}{ Panel A: Management report } \\
\hline SAME_AUDITOR(Partner $)_{i, j}$ & $\begin{array}{l}26.351 * * * \\
(7.300)\end{array}$ & $\begin{array}{l}25.708 * * * \\
(5.115)\end{array}$ & $\begin{array}{l}39.250 * * * \\
(8.232)\end{array}$ \\
\hline SAME_INDUSTRY $Y_{i, j}$ & $\begin{array}{l}4.363 * * * \\
(11.372)\end{array}$ & $\begin{array}{l}9.120 * * * \\
(11.025)\end{array}$ & $\begin{array}{l}2.448 * * * \\
(2.752)\end{array}$ \\
\hline SAME_REGION ${ }_{i, j}$ & $\begin{array}{l}2.449 * * * \\
(9.551)\end{array}$ & $\begin{array}{l}3.007 * * * \\
(6.234)\end{array}$ & $\begin{array}{l}1.693 * * \\
(2.572)\end{array}$ \\
\hline SAME_ACCOUNTS $_{\mathrm{i}, \mathrm{j}}$ & $\begin{array}{l}2.949 * * * \\
(10.878)\end{array}$ & $\begin{array}{l}2.575 * * * \\
(5.067)\end{array}$ & $\begin{array}{l}32.455^{* * * *} \\
(22.089)\end{array}$ \\
\hline SIZE_SIMILARITY $_{\mathrm{i}, \mathrm{j}}$ & $\begin{array}{l}2.387 * * * \\
(12.628)\end{array}$ & $\begin{array}{l}4.036 * * * \\
(13.095)\end{array}$ & $\begin{array}{l}0.473 \\
(1.541)\end{array}$ \\
\hline ROA_SIMILARITY $_{i, j}$ & $\begin{array}{l}0.105 * * * \\
(9.485)\end{array}$ & $\begin{array}{l}0.203 * * * \\
(7.930)\end{array}$ & $\begin{array}{l}0.028 \\
(1.417)\end{array}$ \\
\hline GROWTH_SIMILARITY $_{\mathrm{i}, \mathrm{j}}$ & $\begin{array}{l}0.060 * * * \\
(16.466)\end{array}$ & $\begin{array}{l}0.200 * * * \\
(12.360)\end{array}$ & $\begin{array}{l}0.010 \\
(1.300)\end{array}$ \\
\hline LEVERAGE_SIMILARITY $_{\mathrm{i}, \mathrm{j}}$ & $\begin{array}{l}0.078 * * * \\
(4.290)\end{array}$ & $\begin{array}{l}0.121 * * * \\
(3.361)\end{array}$ & $\begin{array}{l}0.051 \\
(1.547)\end{array}$ \\
\hline LENGTH_SIMILARITY $_{\mathrm{i}, \mathrm{j}}$ & $\begin{array}{l}0.001 * * * \\
(15.941)\end{array}$ & $\begin{array}{l}0.005 * * * \\
(20.301)\end{array}$ & $\begin{array}{l}0.001 * * * \\
(5.992)\end{array}$ \\
\hline SAME_PUBLIC_PRIVATE $_{\mathrm{i}, \mathrm{j}}$ & $\begin{array}{l}8.642 * * * \\
(13.749)\end{array}$ & $\begin{array}{l}26.021 * * * \\
(12.614)\end{array}$ & $\begin{array}{l}11.661 * * * \\
(7.582)\end{array}$ \\
\hline Client firm $_{\mathrm{i}} \times$ Year FE & Yes & Yes & Yes \\
\hline Client firm $_{j} \times$ Year FE & Yes & Yes & Yes \\
\hline Adjusted $R^{2}$ & 0.610 & 0.572 & 0.143 \\
\hline Observations & $3,281,423$ & $3,165,993$ & $3,281,423$ \\
\hline \multicolumn{4}{|l|}{ Panel B: Notes } \\
\hline SAME_AUDITOR(Partner $)_{i, j}$ & $\begin{array}{l}39.476 * * * \\
(11.921)\end{array}$ & $\begin{array}{l}39.661 * * * \\
(5.220)\end{array}$ & $\begin{array}{l}79.201 * * * \\
(12.552)\end{array}$ \\
\hline SAME_INDUSTRY $_{i, j}$ & $\begin{array}{l}2.698 * * * \\
(9.527)\end{array}$ & $\begin{array}{l}3.752 * * * \\
(4.532)\end{array}$ & $\begin{array}{l}2.658 * * * \\
(2.790)\end{array}$ \\
\hline SAME_REGION $_{\mathrm{i}, \mathrm{j}}$ & $\begin{array}{l}4.118 * * * \\
(13.760)\end{array}$ & $\begin{array}{l}1.761 * * * \\
(4.197)\end{array}$ & $\begin{array}{l}1.684 * * * \\
(2.617)\end{array}$ \\
\hline SAME_ACCOUNTS $_{\mathrm{i}, \mathrm{j}}$ & $\begin{array}{l}13.044 * * * \\
(42.570)\end{array}$ & $\begin{array}{l}39.969 * * * \\
(38.471)\end{array}$ & $\begin{array}{l}36.893^{* * * *} \\
(24.641)\end{array}$ \\
\hline SIZE_SIMILARITY ${ }_{i, j}$ & $\begin{array}{l}1.066 * * * \\
(8.558)\end{array}$ & $\begin{array}{l}5.898 * * * \\
(13.228)\end{array}$ & $\begin{array}{l}0.295 \\
(0.895)\end{array}$ \\
\hline
\end{tabular}


Table 2 (continued)

\begin{tabular}{|c|c|c|c|}
\hline & WORDING_SIM ${ }_{\mathrm{i}, \mathrm{j}}$ & CONTENT_SIM & STRUCTURE_SIM $_{\mathrm{i}}$, \\
\hline \multirow[t]{2}{*}{ ROA_SIMILARITY $_{i, j}$} & $0.061 * * *$ & $0.176 * * *$ & $0.076^{* * *}$ \\
\hline & $(6.711)$ & $(5.722)$ & $(2.986)$ \\
\hline \multirow[t]{2}{*}{ GROWTH_SIMILARITY $_{\mathrm{i}, \mathrm{j}}$} & $0.019 * * *$ & $0.039 * * *$ & 0.009 \\
\hline & $(6.658)$ & $(6.430)$ & $(1.165)$ \\
\hline \multirow[t]{2}{*}{ LEVERAGE_SIMILARITY $_{i, j}$} & $0.056 * * *$ & $0.112 * *$ & 0.008 \\
\hline & (4.279) & $(2.156)$ & $(0.272)$ \\
\hline \multirow[t]{2}{*}{ LENGTH_SIMILARITY $_{\mathrm{i}, \mathrm{j}}$} & $0.005 * * *$ & $0.015 * * *$ & $0.002 * * *$ \\
\hline & $(14.049)$ & $(16.871)$ & $(7.832)$ \\
\hline \multirow[t]{2}{*}{ SAME_PUBLIC_PRIVATE $_{\mathrm{i}, \mathrm{j}}$} & $41.143 * * *$ & $104.440 * * *$ & $7.868 * * *$ \\
\hline & $(14.328)$ & $(15.141)$ & $(4.636)$ \\
\hline Client firm $\mathrm{i} \times$ Year FE & Yes & Yes & Yes \\
\hline Client firm $_{\mathrm{j}} \times$ Year FE & Yes & Yes & Yes \\
\hline Adjusted $R^{2}$ & 0.748 & 0.839 & 0.148 \\
\hline Observations & $3,126,215$ & $3,093,740$ & $3,086,503$ \\
\hline
\end{tabular}

This table presents the relation between sharing an audit partner and textual similarity of narrative disclosures. Panel A (Panel B) presents the results for management reports (notes). In Column 1, the dependent variable WORDING_SIM ${ }_{i, j}$ is the cosine of the angle between the IDF-weighted term frequency vectors of management reports or notes $i$ and $j$, multiplied by 100. In Column 2, the dependent variable CONTENT_SIM $i_{i, j}$ is the cosine of the angle between the topic vectors of management reports or notes $i$ and $j$, multiplied by 100 . In Column 3, the dependent variable STRUCTURESIM $i, j$ is the cosine of the angle between the headline vectors, which contain the exact headings of management reports or notes $i$ and $j$, multiplied by 100. All three dependent variables are log-transformed and multiplied by 100 . $S A M E \_$AUDITOR(Partner $)_{i, j}$ is an indicator variable that equals one if client firms $i$ and $j$ share the same audit partner in a year, and zero otherwise. SAME_INDUSTRY $Y_{i, j}$ is an indicator variable that equals one if client firms $i$ and $j$ share the same two-digit SIC industry code, and zero otherwise. SAME_REGION $i, j$ is an indicator variable that equals one if client firms $i$ and $j$ are based in the same region, and zero otherwise. SAME_ACCOUNTS $S_{i, j}$ is an indicator variable that equals one if both client firms $i$ and $j$ prepare their annual report either on a single entity or on a consolidated basis, and zero otherwise. SIZE_SIMILARITY ${ }_{i, j}$ is the absolute difference in the logarithm of total assets of client firms $i$ and $j$, multiplied by minus one. ROA_SIMILARITY $Y_{i, j}\left(\right.$ GROWTH_SIMILARITY $_{i, j}$, LEVERAGE_SIMILARITY $\left._{i, j}\right)$ is the absolute difference in ROA (revenue growth measured as the change in total sales from year t- 1 to $\mathrm{t}$ scaled by total sales in $\mathrm{t}-1$, leverage measured as total debt scaled by total assets) of client firms $i$ and $j$, multiplied by minus one. LENGTH_SIMILARITY ${ }_{i, j}$ is the absolute difference in the number of words of management reports or notes $i$ and $j$, multiplied by minus one. SAME_PUBLIC_PRIVATE $E_{i, j}$ is an indicator variable that equals one if client firms $i$ and $j$ are either both public or private, and zero otherwise. In all three regressions, we include client firm $i$-by year and client firm $j$-by year fixed effects. We cluster standard errors on client firm $i$ 's and client firm $j$ 's audit partners. Differences in the pre-processing of our algorithms lead to different sample sizes for WORDING_SIM ${ }_{i, j}$, CONTENT_SIM ${ }_{i, j}$, and STRUCTURE_SIM $M_{i, j}$. Robust t-statistics are reported in parentheses. $*$, **, and $* * *$ denote statistical significance at the $0.10,0.05$, and 0.01 levels (two-tailed tests), respectively

Next, we exploit the granularity of our data and analyze how the influence of audit offices and firms compares to our main results for audit partners. Specifically, we introduce two additional variables to our main regression, $S A M E A U D I T O R(O f f i c e)_{i, j}$ 
and $S A M E \_A U D I T O R(\text { Firm })_{i, j}$. SAME_AUDITOR $(\text { Office })_{i, j}$ equals one when client firms $i$ and $j$ are audited by the same audit office but not the same audit partner, and zero otherwise. $S A M E \_$AUDITOR(Firm $)_{i, j}$ equals one if a client firm-pair is audited by the same firm but not by the same office or partner, and zero otherwise. These variables help us isolate the differences in the effects of audit partners, offices, and firms.

Column 1 of Table 3 shows the results for wording similarity. Whereas the main effect for audit partners remains at 30 percent, we find that the increase in similarity when sharing the same audit firm is substantially lower, at 2.3 percent. The increase in wording similarity when sharing the same audit office is approximately 5 percent. This pattern is similar for the other proxies. For example, content similarity (structure similarity) increases by 4.5 percent (16 percent) at the audit firm level, by 9.3 percent (28 percent) at the audit office level, and by 30 percent ( 48 percent) at the audit partner level. Overall, the effect of sharing the same audit partner is substantially stronger than the effect of sharing only the same audit office or firm. The results and inferences are similar for the notes (see Panel B). However, the magnitude of the audit firm and audit office relative to the audit partner influence is higher for the notes, which may result from the notes containing more standardized contents (see higher baseline similarity for the notes in Table 1) and, hence, better allowing the application of standardized audit firm or audit office templates. Overall, although our results support the findings of DeFranco et al. (2020) that audit firms and offices play a role for their client firms' narrative disclosures, we find that it is the audit partner who influences client firms' narrative disclosures the most.

\subsection{When do audit partners influence their clients' narrative disclosures?}

Next, we identify situations in which audit partners are more likely to exert an influence. First, we test whether the relationship between sharing an audit partner and the degree of textual similarity of the clients' narrative disclosures is different for small client firms. We define a client firm as small if its total assets are below the sample median in a given year. Specifically, smaller client firms with fewer resources may have relatively higher production costs because of their lack of expertise. Second, we investigate the differences between Big 4 and non-Big 4 auditors. Big 4 firm audit partners may have better scaling effects to spread the costs of gaining expertise over a larger client base and, thus, lower production costs. Furthermore, audit partners from Big 4 audit firms may be more confident in their professional judgment and style (Chen et al. 2020), thereby showing a greater tendency to support clients. However, Big 4 audit firms also have more streamlined auditing processes and work guidelines, which could leave less room for audit partners in their interactions with clients and make it costlier for audit partners to circumvent guidelines. Moreover, Big 4 audit firms have higher reputational capital, and their audit partners may face higher costs when intervening directly and risking litigation. Hence, we expect the relationship between sharing an audit partner and the degree of textual similarity to be weaker for Big 4 auditors. Finally, we test whether this relationship differs for public and private firms. Public firms may have more financial reporting expertise and resources, which makes the in-house production of narrative disclosures less costly. Furthermore, the 
Table 3 Analysis of audit partners, audit offices, and audit firms

\begin{tabular}{|c|c|c|c|}
\hline & WORDING_SIM ${ }_{\mathrm{i}, \mathrm{j}}$ & CONTENT_SIM ${ }_{i, j}$ & STRUCTURE_SIM $_{\mathrm{i}, \mathrm{j}}$ \\
\hline \multicolumn{4}{|l|}{ Panel A: Management report } \\
\hline SAME_AUDITOR(Partner) $)_{i, j}$ & $\begin{array}{l}26.455 * * * \\
(7.333)\end{array}$ & $\begin{array}{l}25.905^{* * * *} \\
(5.158)\end{array}$ & $\begin{array}{l}39.879 * * * \\
(8.354)\end{array}$ \\
\hline SAME_AUDITOR(Office $)_{i, j}$ & $\begin{array}{l}4.870 * * * \\
(5.752)\end{array}$ & $\begin{array}{l}8.501 * * * \\
(5.464)\end{array}$ & $\begin{array}{l}24.871 * * * \\
(6.888)\end{array}$ \\
\hline SAME_AUDITOR(Firm $)_{i, j}$ & $\begin{array}{l}2.232 * * * \\
(5.535)\end{array}$ & $\begin{array}{l}4.407 * * * \\
(5.217)\end{array}$ & $\begin{array}{l}15.097 * * * \\
(8.572)\end{array}$ \\
\hline Controls & Yes & Yes & Yes \\
\hline Client firm $_{\mathrm{i}} \times$ Year FE & Yes & Yes & Yes \\
\hline 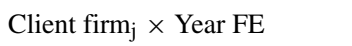 & Yes & Yes & Yes \\
\hline Adjusted $R^{2}$ & 0.611 & 0.572 & 0.143 \\
\hline Observations & $3,281,423$ & $3,165,993$ & $3,281,423$ \\
\hline \multicolumn{4}{|l|}{ Panel B: Notes } \\
\hline SAME_AUDITOR(Partner) $)_{i, j}$ & $\begin{array}{l}39.784 * * * \\
(12.106)\end{array}$ & $\begin{array}{l}39.988^{* * * *} \\
(5.271)\end{array}$ & $\begin{array}{l}80.913 * * * \\
(12.735)\end{array}$ \\
\hline SAME_AUDITOR(Office $)_{i, j}$ & $\begin{array}{l}13.662 * * * \\
(10.932)\end{array}$ & $\begin{array}{l}15.610^{* * * *} \\
(7.252)\end{array}$ & $\begin{array}{l}63.472 * * * \\
(7.444)\end{array}$ \\
\hline SAME_AUDITOR(Firm $)_{i, j}$ & $\begin{array}{l}7.102^{* * *} \\
(9.279)\end{array}$ & $\begin{array}{l}6.919 * * * \\
(5.456)\end{array}$ & $\begin{array}{l}42.650 * * * \\
(8.748)\end{array}$ \\
\hline Controls & Yes & Yes & Yes \\
\hline Client firm $_{\mathrm{i}} \times$ Year FE & Yes & Yes & Yes \\
\hline 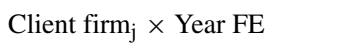 & Yes & Yes & Yes \\
\hline Adjusted $R^{2}$ & 0.749 & 0.839 & 0.153 \\
\hline Observations & $3,126,215$ & $3,093,740$ & $3,086,503$ \\
\hline
\end{tabular}

This table presents the relation between sharing an audit partner, an audit office, or an audit firm, and textual similarity of narrative disclosures. Panel A (Panel B) presents the results for management reports (notes). In Column 1, the dependent variable WORDING_SIM ${ }_{i, j}$ is the cosine of the angle between the IDFweighted term frequency vectors of management reports or notes $i$ and $j$, multiplied by 100 . In Column 2, the dependent variable CONTENT_SIM ${ }_{i, j}$ is the cosine of the angle between the topic vectors of management reports or notes $i$ and $j$, multiplied by 100. In Column 3, the dependent variable STRUCTURE_SIM ${ }_{i, j}$ is the cosine of the angle between the headline vectors, which contain the exact headings of management reports or notes $i$ and $j$, multiplied by 100 . All three dependent variables are log-transformed and multiplied by 100. SAME_AUDITOR(Partner $)_{i, j}$ is an indicator variable that equals one if client firms $i$ and $j$ share the same audit partner in a year, and zero otherwise. SAME_AUDITOR $(O f f i c e)_{i, j}$ is an indicator variable that equals one if client firms $i$ and $j$ share the same audit office in a year but not the same audit partner, and zero otherwise. SAME_AUDITOR(Firm $)_{i, j}$ is an indicator variable that equals one if client firms $i$ and $j$ share the same audit firm in a year but not the same audit office or partner, and zero otherwise. In all three regressions, we use the same control variables as in our main model and include client firm $i$-by year and client firm $j$-by year fixed effects. We cluster standard errors on client firm $i$ 's and $j$ 's audit partners. Differences in the pre-processing of our algorithms lead to different sample sizes for WORDING_SIM ${ }_{i, j}$, CONTENT SIM $i, j$, and STRUCTURE_SIM $i, j$. Robust t-statistics are reported in parentheses. *, **, and *** denote statistical significance at the $0.10,0.05$, and 0.01 levels (two-tailed tests), respectively 
stakeholder base is generally broader for publicly listed firms, which may render communication through narrative disclosures more important and incentivize highquality disclosures that go beyond mere GAAP compliance. In these cases, it may be cheaper for client firms to produce such disclosures if they are particularly firm specific. Additionally, public client firms are subject to greater regulatory requirements. These requirements substantially determine the narrative disclosures of public firms; hence, they reduce the discretion in client firms' narrative reporting (Dyer et al. 2017) and the room for audit partners to exert an influence. Thus, we expect the auditor effect to be less pronounced for public firms than for private firms.

For these analyses, we define an indicator variable BOTH_SMALL $L_{i, j}$, which equals one if client firms $i$ and $j$ are both small, and zero otherwise. BOTH_BIG $4_{i, j}$ equals one if client firms $i$ and $j$ are both audited by a Big 4 audit partner, and zero otherwise. BOTH_PUBLIC $C_{i, j}$ equals one if client firms $i$ and $j$ are both publicly listed, and zero otherwise. We interact these variables with SAME_AUDITOR(Partner) $)_{i, j}{ }^{30}$

Table 4 reports the results for the small-versus-large analysis. In Panel A, the coefficient on $S A M E \_A U D I T O R_{i, j} \times B_{O T H} S M A L L_{i, j}$ is positive and statistically significant for one of the similarity proxies, indicating that the relationship between sharing an audit partner and the similarity of management reports is stronger for small client firms. Panel B reports the results for the notes. Here, the interaction term is significantly positive for all three similarity proxies.

Table 5 shows the results for the Big 4-versus-non-Big 4 analysis. Panels A and B show that the relationship between sharing an audit partner and the similarity of narrative disclosures is significantly weaker for client firms that are audited by a Big 4 firm in all specifications.

In Table 6, the relationship between sharing an audit partner and client firm-pair textual similarity is stronger for private client firms. The magnitude of the coefficients suggests that the influence of audit partners is concentrated among private client firms and largely disappears for public client firms.

Overall, these cross-sectional tests show that our main effect is stronger for small firms, non-Big 4 audit partners, and private firms. Hence, audit partners are not equally involved in all client firms' preparation of narrative disclosures. Rather, audit partners seem to be more strongly involved with client firms that have lower financial reporting expertise (small client firms) or incentives (private client firms), and play an important role for the preparation of narrative disclosures for these firms.

\subsection{How do audit partners influence narrative disclosures?}

The previous results suggest that audit partners influence their clients' narrative disclosures to a significant extent, particularly in specific situations. However, it is unclear how this influence is exerted. For example, it is possible that audit partners simply introduce standard text modules or boilerplate phrases into their clients'

\footnotetext{
${ }^{30} \mathrm{We}$ run the cross-sectional tests on sub-samples that comprise client firm-pairs, where client firms $i$ and $j$ are either both small (audited by a Big 4 auditor, public) or both large (audited by a non-Big 4 auditor, private). Therefore, the main effects of $B O T H_{-} S M A L L_{i, j}, B O T B_{B} B I G 4_{i, j}$, and $B O T H \_P U B L I C_{i, j}$ are omitted because they are perfectly collinear with the fixed effects.
} 
Table 4 Analysis for small versus large client firms

WORDING_SIM ${ }_{i, j} \quad$ CONTENT_SIM ${ }_{i, j} \quad$ STRUCTURE_SIM $i, j$

\begin{tabular}{|c|c|c|c|}
\hline \multicolumn{4}{|l|}{ Panel A: Management report } \\
\hline \multirow[t]{2}{*}{ SAME_AUDITOR(Partner) $)_{\mathrm{i}, \mathrm{j}}$} & $25.407 * * *$ & $27.678^{* * * *}$ & $31.619 * * *$ \\
\hline & $(4.568)$ & $(3.220)$ & $(5.218)$ \\
\hline \multirow[t]{2}{*}{ SAME_AUDITOR $_{\mathrm{i}, \mathrm{j}} \times$ BOTH_SMALL $\mathrm{L}_{\mathrm{i}, \mathrm{j}}$} & 9.236 & -3.715 & $31.077 * *$ \\
\hline & $(1.239)$ & $(-0.401)$ & $(2.531)$ \\
\hline Controls & Yes & Yes & Yes \\
\hline Client firm $_{\mathrm{i}} \times$ Year FE & Yes & Yes & Yes \\
\hline Client firm $_{j} \times$ Year FE & Yes & Yes & Yes \\
\hline Adjusted $R^{2}$ & 0.612 & 0.578 & 0.150 \\
\hline Observations & $2,478,881$ & $2,391,148$ & $2,478,881$ \\
\hline \multicolumn{4}{|l|}{ Panel B: Notes } \\
\hline \multirow[t]{2}{*}{ SAME_AUDITOR(Partner $)_{\mathrm{i}, \mathrm{j}}$} & $34.095 * * *$ & $33.758^{* * *}$ & $68.511 * * *$ \\
\hline & (7.957) & $(4.476)$ & $(10.284)$ \\
\hline \multirow[t]{2}{*}{ SAME_AUDITOR $_{\mathrm{i}, \mathrm{j}} \times$ BOTH_SMALL $\mathrm{i}_{\mathrm{i}, \mathrm{j}}$} & $20.468 * * *$ & $21.972 * *$ & $43.785 * * *$ \\
\hline & $(3.001)$ & $(2.272)$ & $(3.010)$ \\
\hline Controls & Yes & Yes & Yes \\
\hline Client firm $_{\mathrm{i}} \times$ Year FE & Yes & Yes & Yes \\
\hline Client firm $_{j} \times$ Year FE & Yes & Yes & Yes \\
\hline Adjusted $R^{2}$ & 0.742 & 0.845 & 0.158 \\
\hline Observations & $2,360,107$ & $2,334,033$ & $2,329,273$ \\
\hline
\end{tabular}

This table presents the cross-sectional analysis for the effect of client firms $i$ and $j$ sharing the same audit partner on wording, content, and structure similarity, respectively, differentiating between small and large client firms. We define a client firm pair as small (large) if both client firms $i$ and $j$ have below-median (above-median) total assets in a year. Panel A (Panel B) presents the results for management reports (notes). In Column 1, the dependent variable WORDING_SIM , $_{i, j}$ is the cosine of the angle between the IDFweighted term frequency vectors of management reports or notes $i$ and $j$, multiplied by 100 . In Column 2, the dependent variable CONTENT_SIM ${ }_{i, j}$ is the cosine of the angle between the topic vectors of management reports or notes $i$ and $j$, multiplied by 100. In Column 3, the dependent variable STRUCTURE_SIM ${ }_{i, j}$ is the cosine of the angle between the headline vectors, which contain the exact headings of management reports or notes $i$ and $j$, multiplied by 100. All three dependent variables are log-transformed and multiplied by 100. SAME_AUDITOR(Partner $)_{i, j}$ is an indicator variable that equals one if client firms $i$ and $j$ share the same audit partner in a year, and zero otherwise. BOTH_SMALL $L_{i, j}$ is an indicator variable that equals one if both client firms $i$ and $j$ have below-median total assets in a year, and zero otherwise. In all three regressions, we use the same control variables as in our main model and include client firm $i$-by year and client firm $j$-by year fixed effects. We cluster standard errors on client firm $i$ 's and $j$ 's audit partners. We only include observations where client firms $i$ and $j$ are both small or both large. Differences in the pre-processing of our algorithms lead to different sample sizes for WORDING_SIM $i, j$, CONTENT_SIM CON,j $_{\text {, }}$ and STRUCTURE_SIM $M_{i, j}$. Robust t-statistics are reported in parentheses. *, **, and *** denote statistical significance at the $0.10,0.05$, and 0.01 levels (two-tailed tests), respectively 
Table 5 Analysis for Big 4 versus non-Big 4 audit partners

\section{WORDING_SIM ${ }_{i, j} \quad$ CONTENT_SIM ${ }_{i, j} \quad$ STRUCTURE_SIM $_{i, j}$}

\begin{tabular}{|c|c|c|c|}
\hline \multicolumn{4}{|l|}{ Panel A: Management report } \\
\hline SAME_AUDITOR(Partner $)_{\mathrm{i}, \mathrm{j}}$ & $34.719 * * *$ & $35.103 * * *$ & $42.313 * * *$ \\
\hline & $(7.435)$ & $(5.185)$ & $(6.821)$ \\
\hline \multirow[t]{2}{*}{ SAME_AUDITOR ${ }_{i, j} \times$ BOTH_BIG_ $4_{i, j}$} & $-26.939 * * *$ & $-29.513 * * *$ & $-17.315^{* *}$ \\
\hline & $(-5.210)$ & $(-4.023)$ & $(-2.094)$ \\
\hline Controls & Yes & Yes & Yes \\
\hline Client firm $_{\mathrm{i}} \times$ Year FE & Yes & Yes & Yes \\
\hline Client firm $_{j} \times$ Year FE & Yes & Yes & Yes \\
\hline Adjusted $R^{2}$ & 0.606 & 0.549 & 0.159 \\
\hline Observations & $2,013,909$ & $1,932,546$ & $2,013,909$ \\
\hline \multicolumn{4}{|l|}{ Panel B: Notes } \\
\hline \multirow[t]{2}{*}{ SAME_AUDITOR(Partner $)_{\mathrm{i}, \mathrm{j}}$} & $48.639 * * *$ & $54.237 * * *$ & $86.371 * * *$ \\
\hline & $(12.364)$ & $(5.222)$ & $(11.255)$ \\
\hline \multirow[t]{2}{*}{ SAME_AUDITOR ${ }_{i, j} \times$ BOTH_BIG_ $4_{i, j}$} & $-33.664 * * *$ & $-48.468 * * *$ & $-43.300 * * *$ \\
\hline & $(-7.344)$ & $(-4.490)$ & $(-4.203)$ \\
\hline Controls & Yes & Yes & Yes \\
\hline Client firm $_{\mathrm{i}} \times$ Year FE & Yes & Yes & Yes \\
\hline Client firm $_{j} \times$ Year FE & Yes & Yes & Yes \\
\hline Adjusted $R^{2}$ & 0.749 & 0.800 & 0.179 \\
\hline Observations & $1,927,814$ & $1,904,346$ & $1,893,222$ \\
\hline
\end{tabular}

This table presents the cross-sectional analysis for the effect of client firms $i$ and $j$ sharing the same audit partner on wording, content, and structure similarity, respectively, differentiating between Big 4 auditors and non-Big 4 auditors. Panel A (Panel B) presents the results for management reports (notes). In Column 1 , the dependent variable WORDING_SIM ${ }_{i, j}$ is the cosine of the angle between the IDF-weighted term frequency vectors of management reports or notes $i$ and $j$, multiplied by 100 . In Column 2, the dependent variable CONTENT_SIM ${ }_{i, j}$ is the cosine of the angle between the topic vectors of management reports or notes $i$ and $j$, multiplied by 100 . In Column 3, the dependent variable STRUCTURE_SIM ${ }_{i, j}$ is the cosine of the angle between the headline vectors, which contain the exact headings of management reports or notes $i$ and $j$, multiplied by 100 . All three dependent variables are log-transformed and multiplied by 100 . SAME_AUDITOR(Partner $)_{i, j}$ is an indicator variable that equals one if client firms $i$ and $j$ share the same audit partner in a year, and zero otherwise. BOTH_BIG_ $4_{i, j}$ is an indicator variable that equals one if both client firms $i$ and $j$ have a Big 4 auditor, and zero otherwise. In all three regressions, we use the same control variables as in our main model and include client firm $i$-by year and client firm $j$-by year fixed effects. We cluster standard errors on client firm $i$ 's and $j$ 's audit partners. We only include observations where client firms $i$ and $j$ are either both audited by a Big 4 auditor or both not. Differences in the pre-processing of our algorithms lead to different sample sizes for WORDING_SIM ${ }_{i, j}$, CONTENT_SIM $i, j$, and STRUCTURE_SIM ${ }_{i, j}$. Robust t-statistics are reported in parentheses. *, **, and *** denote statistical significance at the $0.10,0.05$, and 0.01 levels (two-tailed tests), respectively

narratives. Alternatively, it could be that audit partners are directly involved in the preparation process of narrative disclosures and thereby introduce client-specific, relevant information. Moreover, the mechanisms of the audit partners' influence are also 
Table 6 Analysis for public versus private client firms

WORDING_SIM $_{\mathrm{i}, \mathrm{j}} \quad$ CONTENT_SIM ${ }_{\mathrm{i}, \mathrm{j}} \quad$ STRUCTURE_SIM $_{\mathrm{i}, \mathrm{j}}$

\begin{tabular}{|c|c|c|c|}
\hline \multicolumn{4}{|l|}{ Panel A: Management report } \\
\hline SAME_AUDITOR(Partner $)_{\mathrm{i}, \mathrm{j}}$ & $29.900 * * *$ & $29.641 * * *$ & $44.188^{* * *}$ \\
\hline & $(7.399)$ & $(5.186)$ & $(8.224)$ \\
\hline \multirow[t]{2}{*}{ SAME_AUDITOR $_{\mathrm{i}, \mathrm{j}} \times$ BOTH_PUBLIC $\mathrm{i}_{\mathrm{i}, \mathrm{j}}$} & -16.537 & $-39.704 * * *$ & $-32.909 * * *$ \\
\hline & $(-1.498)$ & $(-4.247)$ & $(-3.346)$ \\
\hline Controls & Yes & Yes & Yes \\
\hline Client firm $_{\mathrm{i}} \times$ Year FE & Yes & Yes & Yes \\
\hline Client firm $_{j} \times$ Year FE & Yes & Yes & Yes \\
\hline Adjusted $R^{2}$ & 0.610 & 0.519 & 0.151 \\
\hline Observations & $2,678,139$ & $2,577,003$ & $2,678,139$ \\
\hline \multicolumn{4}{|l|}{ Panel B: Notes } \\
\hline \multirow[t]{2}{*}{ SAME_AUDITOR(Partner $)_{\mathrm{i}, \mathrm{j}}$} & $44.381 * * *$ & $45.258 * * *$ & $90.099 * * *$ \\
\hline & $(12.523)$ & $(5.006)$ & $(13.275)$ \\
\hline \multirow{2}{*}{ SAME_AUDITOR $_{i, j} \times$ BOTH_PUBLIC $C_{i, j}$} & $-49.327 * * *$ & $-57.755 * * *$ & $-76.725 * * *$ \\
\hline & $(-10.739)$ & $(-4.706)$ & $(-8.674)$ \\
\hline Controls & Yes & Yes & Yes \\
\hline Client firm $_{\mathrm{i}} \times$ Year FE & Yes & Yes & Yes \\
\hline Client firm $_{j} \times$ Year FE & Yes & Yes & Yes \\
\hline Adjusted $R^{2}$ & 0.759 & 0.701 & 0.151 \\
\hline Observations & $2,586,611$ & $2,558,913$ & $2,541,322$ \\
\hline
\end{tabular}

This table presents the cross-sectional analysis for the effect of client firms $i$ and $j$ sharing the same audit partner on wording, content, and structure similarity, respectively, differentiating between public and private client firms. Panel A (Panel B) presents the results for management reports (notes). In Column 1 , the dependent variable WORDING_SIM ${ }_{i, j}$ is the cosine of the angle between the IDF-weighted term frequency vectors of management reports or notes $i$ and $j$, multiplied by 100 . In Column 2, the dependent variable CONTENT_SIM ${ }_{i, j}$ is the cosine of the angle between the topic vectors of management reports or notes $i$ and $j$, multiplied by 100 . In Column 3, the dependent variable STRUCTURE_SIM ${ }_{i, j}$ is the cosine of the angle between the headline vectors, which contain the exact headings of management reports or notes $i$ and $j$, multiplied by 100 . All three dependent variables are log-transformed and multiplied by 100 . $S A M E \_$AUDITOR(Partner $)_{i, j}$ is an indicator variable that equals one if client firms $i$ and $j$ share the same audit partner in a year, and zero otherwise. BOTH_PUBLIC $C_{i, j}$ is an indicator variable that equals one if both client firms $i$ and $j$ are public firms, and zero otherwise. In all three regressions, we use the same control variables as in our main model and include client firm $i$-by year and client firm $j$-by year fixed effects. We cluster standard errors on client firm $i$ 's and $j$ 's audit partners. We only include observations where client firms $i$ and $j$ are both public firms or both private firms. Differences in the pre-processing of our algorithms lead to different sample sizes for WORDING_SIM ${ }_{i, j}$, CONTENT_SIM $i, j$, and STRUCTURE_SIM SO $_{i, j}$. Robust $\mathrm{t}$-statistics are reported in parentheses. *,**, and *** denote statistical significance at the $0.10,0.05$, and 0.01 levels (two-tailed tests), respectively 
Table 7 Non-sticky and non-boilerplate parts of the management report

\begin{tabular}{|c|c|c|}
\hline & NON_STICKY_WORD_SIM & NON_BOILER_WORD_SIM ${ }_{\mathrm{i}, \mathrm{j}}$ \\
\hline SAME_AUDITOR(Partner) $)_{i, j}$ & $\begin{array}{l}26.771 * * * \\
(6.303)\end{array}$ & $\begin{array}{l}36.577 * * * \\
(6.413)\end{array}$ \\
\hline Controls & Yes & Yes \\
\hline Client firm $_{\mathrm{i}} \times$ Year FE & Yes & Yes \\
\hline Client firm $_{j} \times$ Year FE & Yes & Yes \\
\hline Adjusted $R^{2}$ & 0.614 & 0.600 \\
\hline Observations & $2,333,771$ & $3,281,423$ \\
\hline
\end{tabular}

This table presents the relation between sharing an audit partner and wording similarity of the non-sticky and non-boilerplate parts of the management report, respectively. NON_STICKY_WORD_SIM ${ }_{i, j}$ is the cosine of the angle between the IDF-weighted term frequency vectors of the non-sticky parts of management reports $i$ and $j$, multiplied by 100. NON_BOILER_WORD_SIM $i, j$ is the cosine of the angle between the IDF-weighted term frequency vectors of the non-boilerplate parts of management reports $i$ and $j$, multiplied by 100 . Both dependent variables are log-transformed and multiplied by 100. SAME_AUDITOR(Partner $)_{i, j}$ is an indicator variable that equals one if client firms $i$ and $j$ share the same audit partner in a year, and zero otherwise. In both regressions, we use the same control variables as in our main model and include client firm $i$-by year and client firm $j$-by year fixed effects. We cluster standard errors on client firm $i$ 's and $j$ 's audit partners. Robust t-statistics are reported in parentheses. $*$, **, and $* * *$ denote statistical significance at the $0.10,0.05$, and 0.01 levels (two-tailed tests), respectively

unknown. In this section, we shed light on these aspects via a boilerplate test and a qualitative field study.

\subsubsection{Boilerplate test}

If audit partners simply introduce standard text modules or boilerplate phrases into their clients' narratives, such text would not change significantly over time. To test the boilerplate hypothesis, we divide narrative disclosures into sticky and non-sticky parts. Specifically, we follow Dyer et al. (2017), and define a phrase as sticky when the prior year's document contains an identical eight-gram of words. Based on this definition, 29.9 percent of the text is sticky. Next, we exclude the sticky parts from the documents and repeat the main analysis.

Column 1 of Table 7 reports the results. We find that the significant increase in textual similarity persists based on the non-sticky (i.e., new) parts of the narratives. ${ }^{31}$ In Column 2, the results are similar when we exclude boilerplate sentences, which we define as the eight-grams that occur in at least 10 percent of the sample narratives in a year. These findings suggest that audit partner involvement goes beyond merely providing standard text modules and boilerplate phrases to clients. Rather, our results imply that audit partners are closely involved in their clients' financial reporting processes, introducing current and client-specific contents.

\footnotetext{
${ }^{31}$ The number of observations decreases because the focus on the non-sticky parts requires the availability of the prior year's document.
} 


\subsubsection{Field study}

To determine the mechanisms of the audit partner's influence and validate our conclusion from the previous section that audit partners are closely involved in their clients' financial reporting processes, we conducted semi-structured interviews with audit partners. Specifically, we interviewed eight audit partners from different audit firms and with different experience levels. ${ }^{32}$ All interviewees had experience as audit engagement partners. In addition to gaining a better understanding of how audit partners shape narrative disclosures, the interviews also helped us assess whether the associations in our previous empirical tests potentially allow for a causal interpretation. ${ }^{33}$ Overall, the interviews supported the notion that the audit partner plays an important role for the audit of narrative disclosures. Particularly, the auditors noted that the audit of narrative disclosures is largely the engagement partner's responsibility, not the audit team members'.

We also found support for the influence of audit partners on their clients' preparation processes. Consistent with the premise for our presumed mechanism of imperfect first drafts, several auditors noted that the quality of the first drafts of narrative disclosures is "very diverse and partially very bad" or ranges "from medium to bad." Auditors specifically complained that narrative disclosures "are often very thin, and also poorly and imprecisely written." One auditor said that "it often takes two or three loops" until the narrative disclosures reach a publishable form. When asked how exactly auditors may improve quality in these "loops," the interviewees mentioned several channels. For example, one auditor noted that she provided clients with her audit checklists. Another said that "I have told some clients to take a look at what their competitors write." Often, the main issue behind the low quality of first drafts is missing information. In this context, one auditor noted, "You could tell the client that this and that is missing. Alternatively, you could tell them to write it in this or that way. However, this is a gray area where consulting and auditing can get mixed." Another auditor said "You have to show the client their errors and back this up with the regulatory sources. [...] CEOs usually ask why, and then you want to show them that specific disclosures are required by regulation." Other auditors noted that they tell their clients what topics to address. Specifically, one auditor stated that one needs "to make clients aware that certain topics should be discussed."

Auditors also use more direct ways to shape narrative disclosures. One auditor noted that "in terms of wording, I often write management an email explaining why certain passages are not correct or poorly written. [...] Then, I make an alternative wording suggestion, which is usually accepted by the management. This is the normal procedure." Consistent with our theoretical framework and the results of our

\footnotetext{
${ }^{32}$ The interviews were conducted from June 2017 to September 2018 and lasted for an average 50 minutes (minimum 34 minutes; maximum 67 minutes). The average experience span, as auditors, of our interviewees was 15 years (minimum six years; maximum 27 years). Three (three; two) interviewees worked at small (medium-sized; Big 4) audit firms.

${ }^{33} \mathrm{We}$ used a questionnaire that included four lead questions about auditing in general and the audit of narrative disclosures in particular. However, we asked several follow-up questions to better understand the underlying economics of our archival findings.
} 
cross-sectional analyses, the interviewees mentioned the direct influence of auditors on smaller client firms: "Smaller firms need more help. Sure, this is a balancing act between auditing and consulting. [...] The accounting department in these small firms often lacks expertise and there are topics for which they [small firms] depend on us." Similarly, another auditor said, "In small firms that are not well equipped in terms of staff and expertise, preparing good financial statements and a good management report becomes a joint exercise [by auditors and clients]. However, for larger firms, there is more separation [between auditors and clients] because litigation risk increases."

Some auditors were very frank; for example, one Big 4 auditor noted, "It is a balancing act where you easily divert from auditing to preparing. I have experienced this when we take over new clients-especially when their former auditor is small. These clients sometimes expect that they can just send a draft to the auditor, who will get it done for them." Another Big 4 auditor added "For small firms-and this probably should not be said out loud-I could imagine that the auditor actually hits the keyboard in some instances. In these cases, the balancing act between preparation and audit becomes very, very close. However, especially for small firms, the role of the auditor is more of a general service provider, in terms of a consultant. He [the auditor] provides a full service package and he may possibly help a client in drafting the management report." Another auditor from a small audit firm said "I was once asked by a client whether I could write it [the management report]. I declined." In a similar vein, one auditor noted that "some of my clients' former auditors did not seriously separate preparing and auditing. They prepared the notes and attested them. This is, of course, not right, and I do not want to do this. However, sometimes it is difficult to go through with this when your clients have known this procedure for decades. They have not fully understood that the notes are supposed to be prepared by them because they are part of the financial statements, and not by their auditor."

Overall, the interview evidence is consistent with the regression results and supports the notion that audit partners shape their clients' narrative disclosures. Interviewees particularly noted that audit partners drive what topics are addressed and also influence the wording. Similarly, the provision of audit checklists may affect the structure of narrative disclosures. Moreover, several channels through which audit partners influence their clients' narrative disclosures exist. Consistent with the results of our cross-sectional analyses, audit partners seem to be particularly involved in the preparation process if client firms lack expertise or incentives and provide a poor first draft. Finally, the interviewees indicated this involvement goes beyond merely introducing boilerplate text modules and reflects a more direct involvement in the preparation process.

\subsection{What are the consequences of the influence of audit partners on their clients?}

To understand the economic relevance of our findings for the users of financial reports, we shed light on the consequences of audit partner-induced similarities. On one hand, audit partners' influence could lead to more standardized narrative disclosures, reducing the usefulness of these reports (e.g., Brown and Tucker 2011; Hanley and Hoberg 2010). On the other hand, our prior analyses suggest that the involvement 
of audit partners goes beyond merely adding boilerplate text and could thus improve the quality and usefulness of narrative disclosures. To test for these consequences, we analyze whether sharing an audit partner is related to a higher comparability or uniformity of client firms' narrative disclosures. Moreover, we show how the textual characteristics of client firms' narrative disclosures change, which could reflect changes in narrative disclosure quality. Finally, we test whether users can better utilize client firms' narrative disclosures to predict future profitability.

\subsubsection{Comparability versus uniformity}

DeFranco et al. (2011a) suggest that increased financial statement comparability improves the availability and quality of firm information. We apply this idea to narrative disclosures and argue that narrative disclosures are more informative to users if they contain comparable information (i.e., firm-specific information with similar wording) instead of identical information (i.e., interchangeable phrases with identical wording). However, audit partner-related similarities could be a consequence of audit partners suggesting standard text modules to all their client firms, which would lead to more uniform narrative disclosures. Hence, to test whether audit partners' influence translates into a higher comparability or uniformity of client firms' narrative disclosures, we repeat our main analysis for wording similarity but remove sentences with identical eight-grams of words from the two documents of each client firm pair. ${ }^{34}$ Therefore, in this analysis, WORDING_SIM ${ }_{i, j}$ measures the similarity of client firm $i$ 's and $j$ 's documents with respect to comparable but not identical content. If audit partners increase comparability instead of inducing the uniformity of client firms' narrative disclosures, we expect a significantly positive coefficient on SAME_AUDITOR(Partner $)_{i, j}$.

In Table 8, SAME_AUDITOR(Partner $)_{i, j}$ is significantly positive with a magnitude similar to our main results. At the same time, we document a substantially lower baseline similarity among client firms of approximately 1.8 percent, compared to 5 percent in our main specification (untabulated); this finding indicates that identical phrases are, in general, a major source of narrative disclosure similarity. The similar coefficient on SAME_AUDITOR(Partner $)_{i, j}$ suggests that sharing audit partners is related to client firms producing more comparable and thus more useful narrative disclosures.

\subsubsection{Textual characteristics and usefulness for predicting future profitability}

The results in the prior section suggest that audit partner-related similarity reflects more comparable narrative disclosures among client firms. Here, we test whether audit partners also influence textual characteristics and the usefulness of client firms' narrative disclosures for predicting future profitability. For this purpose, we construct

\footnotetext{
${ }^{34}$ Note that this approach differs from the boilerplate test in Section 4.3.1, where we exclude boilerplate text that occurs in more than 10 percent of the narratives in a year, and not, like in this test, client firm-pair specific boilerplate content.
} 
Table 8 Comparability versus uniformity

\begin{tabular}{ll}
\hline & WORDING_SIM $_{\mathrm{i}, \mathrm{j}}$ \\
\hline SAME_AUDITOR(Partner) $\mathrm{i}_{\mathrm{j}} \mathrm{j}$ & $33.303 * * *$ \\
& $(6.048)$ \\
Controls & Yes \\
Client firm $\mathrm{i} \times$ Year FE & Yes \\
Client firm $\mathrm{j} \times$ Year FE & Yes \\
Adjusted $R^{2}$ & 0.495 \\
Observations & $3,281,423$ \\
\hline
\end{tabular}

This table presents the consequences of audit partner-induced textual similarity for the comparability versus uniformity of client firms' management reports. WORDING_SIM ${ }_{i, j}$ is the cosine of the angle between the IDF-weighted term frequency vectors of management reports $i$ and $j$ after removing identical eightgrams of words from both management reports, multiplied by 100 . The variable is log-transformed and multiplied by 100. SAME_AUDITOR(Partner $)_{i, j}$ is an indicator variable that equals one if client firms $i$ and $j$ share the same audit partner in a year, and zero otherwise. We use the same control variables as in our main model and include client firm $i$-by year and client firm $j$-by year fixed effects. We cluster standard errors on client firm $i$ 's and $j$ 's audit partners. Robust t-statistics are reported in parentheses. *, **, and *** denote statistical significance at the $0.10,0.05$, and 0.01 levels (two-tailed tests), respectively

a measure of the degree of audit partner influence following (Chen et al. 2020). ${ }^{35}$ Specifically, we adjust the similarity scores by regressing the raw similarity scores of each similarity measure on the control variables in our main model and include client firm $i$-by year and client firm $j$-by year fixed effects. The residuals from these regressions capture the portion of a client firm-pair's similarity that is related to sharing an audit partner. Next, we calculate a client firm-year measure by considering a client firm's median similarity with all client firms that share the same audit partner in a year, which reflects the magnitude of the audit partner's influence on a client firm's narrative disclosures. Because we conduct our subsequent analyses at the client firmpair level, we calculate the mean value of client firm $i$ 's and $j$ 's median similarity. We follow this procedure for all similarity measures and thereby obtain three values for an audit partner's influence on a client firm-pair (i.e., for wording, content, and structure). To obtain a measure that combines the three dimensions, we create a composite score based on the mean rank of the three similarity measures over a year. We split our sample based on this composite score and determine an indicator variable, $H I G H \_I N V O L V E D \_A U D I T O R_{i, j}$, which equals one if a client firm-pair has an above-median composite score in a year, and zero otherwise. Because we run the tests at the client firm-pair level, the outcome measures are the pair-means of the respective variables.

\footnotetext{
${ }^{35}$ We use the relative strength of audit partner influence as our independent variable of interest, while Chen et al. (2020) use a same auditor dummy. Under our approach, we focus on the differential effect of audit partners that exert a stronger or weaker influence on their clients, whereas Chen et al. (2020) analyze the effect of the incidence of sharing an audit partner. Hence, in this analysis, we only retain client firm-pairs that have the same audit partner, which leads to a smaller sample.
} 
First, we select several properties of narrative disclosures that reflect quality. Specifically, we consider the extent of forward-looking statements FOR$W A R D \_S H A R E_{i, j}$ by the number of words in forward-looking sentences divided by the total number of words in a document. ${ }^{36}$ Additionally, we follow Dyer et al. (2017) and measure the redundancies in narrative disclosures $R E D U N D A N T_{-} S H A R E_{i, j}$ by the number of words in sentences that contain the eight-grams of words that occur at least twice in a document, divided by the total number of words. Similarly, we consider the stickiness of narratives $S T I C K Y_{-} S H A R E_{i, j}$ by the number of words in sentences that contain the eight-grams of words that are repeated from the prior year's document, divided by the total number of words. Finally, we measure misspellings MISSP_SHARE $E_{i, j}$ by the number of misspelled words in a document, divided by the total number of words. Overall, a higher (lower) value of $F O R$ -

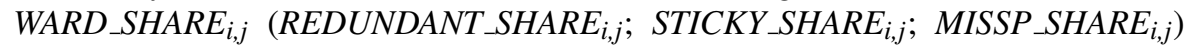
implies higher-quality narrative disclosures.

In Panel A of Table 9, client firms with a more involved audit partner show higherquality narratives. Specifically, although audit partners seem to foster the disclosure of sticky phrases (Column 3), clients' narratives contain significantly more forwardlooking statements (Column 1), fewer redundant phrases (Column 2), and fewer misspellings (Column 4). Overall, these results suggest that audit partners' influence yields more useful and conscientiously shaped narrative disclosures, potentially improving the quality of their clients' narrative disclosures. ${ }^{37}$

Next, to more directly capture the economic relevance of audit partners' influence and the corresponding change in textual characteristics, we test whether the predictive value of narrative disclosures differs when audit partners are more strongly involved with their clients. Particularly, we follow Li (2010) and analyze how the fit of sentiment in forward-looking information in a document and the corresponding client firm's future performance changes depending on the degree of the audit partner's influence. ${ }^{38}$ Specifically, we test the fit of a change in $R O A$ from years $t$ to $t+1$ and the change in sentiment in the forward-looking sentences of the narratives from year $t-1$ to $t .{ }^{39}$ A better alignment of sentiment in forward-looking disclosures and actual future development would imply more useful information for the users of client firms' narrative disclosures.

\footnotetext{
${ }^{36}$ We identify forward-looking sentences by following Höfer (2016).

${ }^{37}$ Following Dyer et al. (2017), we also measure length, boilerplate disclosures, specificity, and readability, but we do not find a significant association with audit partner involvement and, for brevity, do not show the results in Table 10 .

${ }^{38}$ In this test, the focus on the forward-looking parts of narrative disclosures is also consistent with the interview evidence in which auditors mentioned that clients are particularly reluctant to provide sufficient forward-looking disclosures.

${ }^{39}$ We measure sentiment by using a lexicon of sentiment scores for a wide range of German words provided by Remus et al. (2010). As control variables, we use the same client firm-pair variables as in our main model but consider the mean absolute values instead of similarities. Moreover, we focus on management reports because they have been shown to be particularly useful to investors (e.g., Bryan 1997; Barron et al. 1999; Clarkson et al. 1999; Francis et al. 2003; Brown and Tucker 2011). Moreover, as management reports are partly forward-looking and less standardized, they are likely to yield more informative disclosures than notes.
} 


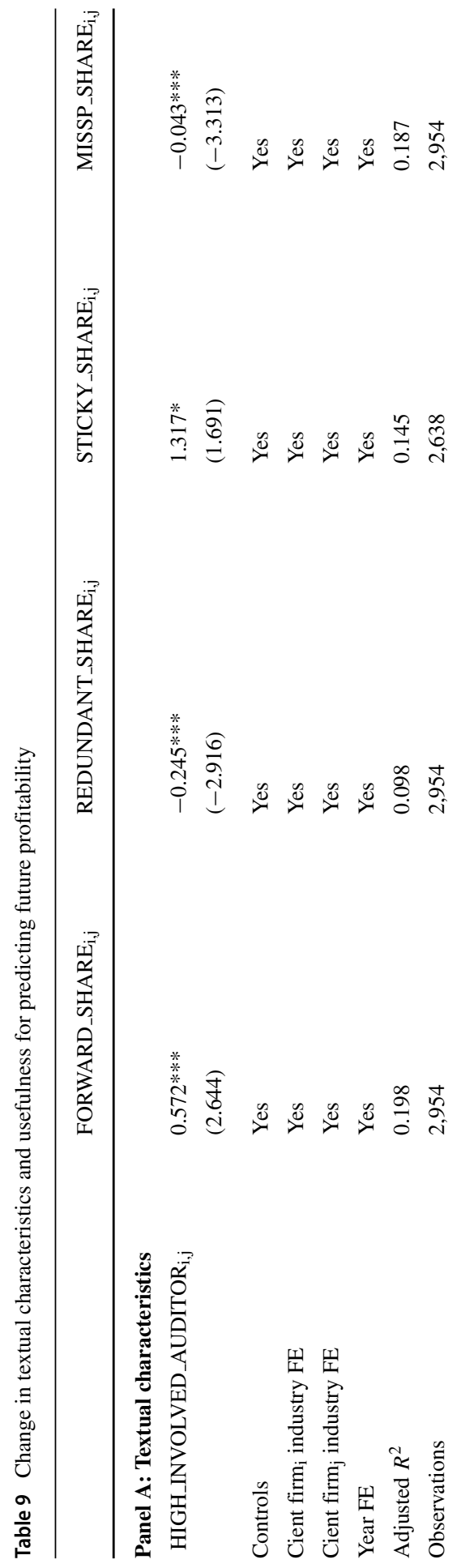




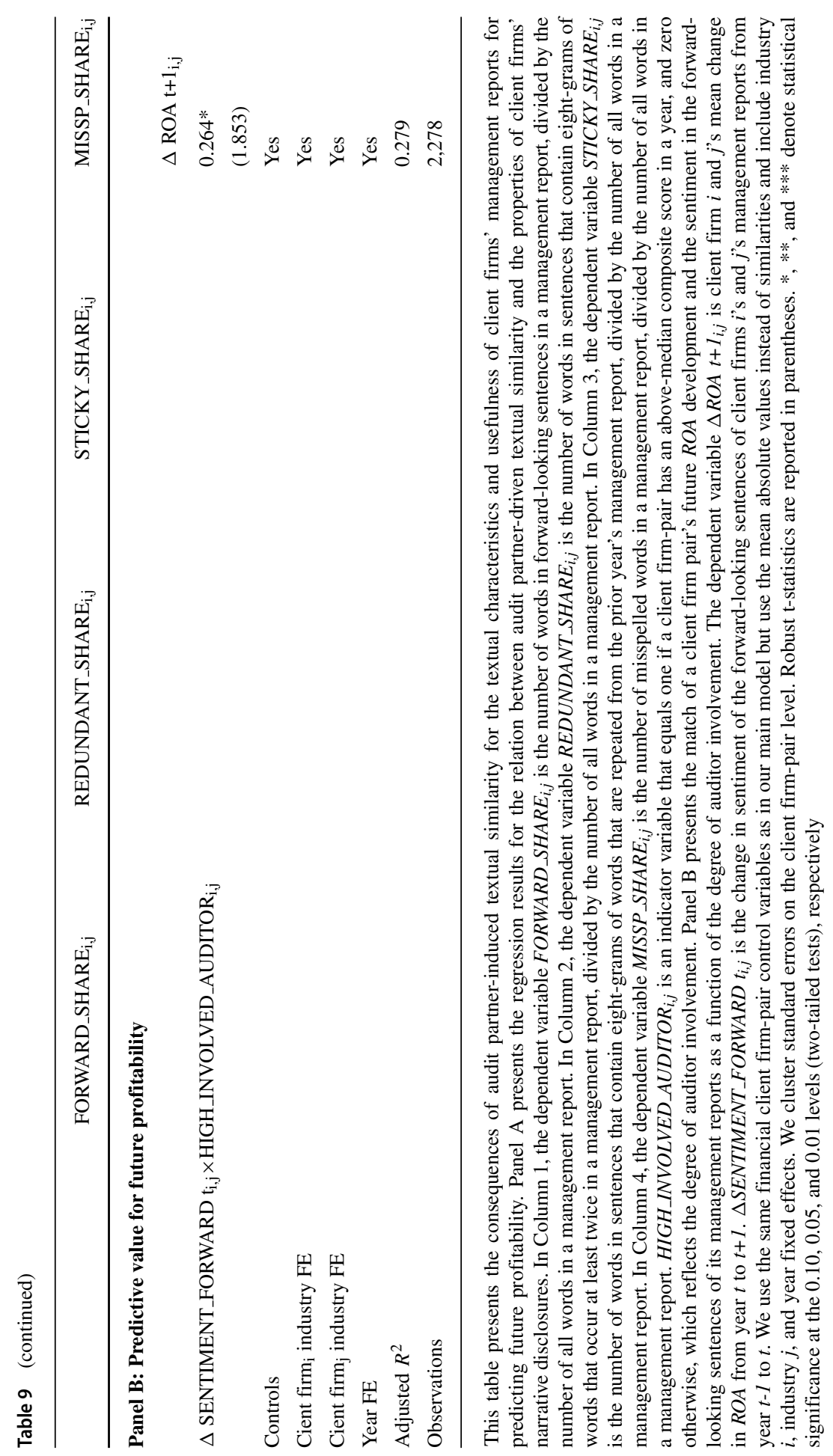


In Panel B of Table 9, the changes in sentiment in the forward-looking parts of the narratives from year $t-1$ to $t$ significantly better explain future changes in $R O A$ from year $t$ to $t+1$ when the auditor is highly involved. This result suggests that highly involved audit partners shape narratives in a way that better reflects a client firm's actual economic situation.

Overall, these findings imply a higher quality of narrative disclosures as a result of the strong audit partner influence. Additionally, this increased quality seems relevant for predicting future profitability.

\subsection{Robustness tests}

Finally, we present several additional robustness tests for our main claim. Specifically, we conduct an analysis of audit partner switches, a falsification test, matched samples tests, and use alternative similarity proxies.

\subsubsection{Auditor switches}

Brown and Knechel (2016) find that client firms tend to switch to audit firms whose other clients are more similar to them. Hence, our results, despite being on an audit partner level, may be driven by reverse causality. To address this concern, we use a change specification. Specifically, we use the instances of audit partner switches in our sample. If an audit partner switch leads to a client firm-pair having the same audit partner after having different audit partners before the switch, we expect that the textual similarity of the client firm-pair's narrative disclosures will increase. Similarly, similarity with old common clients should decrease after switching. To construct a change test, we use our main specification and include client firm-pair fixed effects in addition to the existing fixed effects. In this model, the identification solely stems from client firm-pairs that had audit partner switches during our sample period. At the same time, the client firm $i$-by year, and client firm $j$-by year fixed effects rule out that a potential change in similarity may be driven by a general or firm-specific time trend.

Untabulated results for management reports show a significantly positive coefficient on SAMEAUDITOR(Partner $)_{i, j}$ for wording and structure similarities. For notes, all three proxies show a significant increase (decrease) in similarity after the switch to the same (to a different) audit partner. ${ }^{40}$ In sum, these findings support the results of our main model and rule out reverse causality concerns. The magnitude of the effect and the significance levels may be slightly lower because of the relatively small number of audit partner switches and because it may take some time before the audit partner's influence becomes fully visible across all dimensions. ${ }^{41}$ Overall,

\footnotetext{
${ }^{40}$ Note that this could be driven by an increase in the similarity with new clients, a decrease in the similarity with old clients, or a combination of the two.

${ }^{41}$ Given our sample period of six years, the post-switch period might be too short to observe a more significant audit partner effect for the contents of management reports-especially in those cases when the switch occurred late in the sample period.
} 
these results support the notion that audit partner switches lead the changes in textual similarity, and not vice versa.

\subsubsection{Falsification test}

Next, we test whether the relationship between increased textual similarity and sharing an audit partner disappears for texts where the audit partner is highly unlikely to exert any influence. Specifically, we conjecture that audit partners do not influence the content of their client firm's website. ${ }^{42}$ Hence, we expect that the effect is significantly attenuated when we rerun our main specification based on the text on client firms' websites.

Based on the URLs of our sample client firms from DAFNE, we use the online Wayback Machine to crawl historical websites to obtain a document for each client firm-year. Specifically, we obtain the website of a client firm-year if stored by the Wayback Machine, and drop client firm-years for which the Wayback Machine has no record. ${ }^{43}$ We then crawl the main web page and every second-order page for paragraphs with more than 50 words and store them in a document for every client firm-year. Based on these documents, we apply the same preprocessing steps as for WORDING_SIM W $_{i, j}$ and exhaustively pair within each year, which leaves us with a sample of 356,589 client firm-pairs. ${ }^{44}$ Based on this sample of client firm-pairs, we rerun the main specification with website wording similarity as the dependent variable.

Untabulated results show an insignificant coefficient on SAME_AUDITOR(Partner $)_{i, j}$, which is also very low in magnitude. This is consistent with the notion that the similarity of website content does not change when two client firms share the same audit partner. In line with expectations, most control variables have comparable magnitudes. Particularly, SAME_INDUSTRY ${ }_{i, j}$ and $S A M E \_R E G I O N_{i, j}$ are highly significant. To rule out that the insignificant coefficient on $S A M E A U D I T O R(\text { Partner })_{i, j}$ is due to the smaller sample size, we rerun our main tests with the audited narrative disclosures in the financial report based on the reduced sample from the website regression and find a highly significant coefficient on SAME_AUDITOR(Partner $)_{i, j}$, but slightly smaller in magnitude compared with our main results (19.65 versus 26.35$).{ }^{45}$ Hence, the null result for website text is unlikely to be driven by low power. Overall, these findings serve as an important falsification test, which reduces correlated-omitted variable concerns.

\footnotetext{
${ }^{42}$ We acknowledge that audit partners may have an indirect influence on websites when the contents of financial reports are used for the website. Generally, financial reports are made available in downloadable files, which would not be part of the website text we extract. Moreover, a replication of the contents of financial reports on firm websites would bias our test toward a significant relationship and thus work against the idea of our falsification test.

${ }^{43}$ We also exclude client firms that have a website with top-level domain ".com," because these websites are generally in English.

${ }^{44}$ As with our main similarity proxies, we truncate the similarity of website text at the 99th percentile.

${ }^{45}$ The smaller magnitude is likely because website availability biases this subsample toward larger firms, which is consistent with our cross-sectional results.
} 


\subsubsection{Matched samples}

Another concern of our main results is the low fraction of client firm-pairs that actually share an audit partner. Furthermore, the high number of observations raises the concern of overestimated t-statistics. To address these concerns, we re-estimate the main model using a matched sample of client firm-pairs, in which approximately 50 percent of the observations share an audit partner and 50 percent do not. Particularly, we first model the propensity of a client firm-pair to have the same audit partner, using all client firm-pair control variables from our main model. In the second step, we match each client firm-pair where $S A M E A U D I T O R_{i, j}$ equals one with a client firm-pair that does not share the same audit partner in the same sample year. ${ }^{46}$ The untabulated results based on this much smaller sample (around 2,800 firm-pairs) are similar to those for our main specification, albeit weaker in terms of statistical significance.

\subsubsection{Alternative similarity proxies}

To further assess result robustness, we repeat our main test with alternative similarity proxies. Specifically, for wording, we use the non-proprietary text reuse-detection software WCopyFind, which measures the number of matching string-tokens in two documents and reports the cumulative words of all tokens. We scale the cumulative number of words considered a match between two client firms' narrative disclosures by the average number of words in the documents of client firms $i$ and $j$. Instead of word choice and writing style, as identified by the vector space model, WCopyFind focuses on direct similarity based on common phrases. However, untabulated results show that the results based on WCopyFind are qualitatively similar to those of the vector space model.

Additionally, we use an alternative approach to determine content similarity. Specifically, we employ word embeddings, which is a recent technique in computational linguistics for analyzing semantics. In word embeddings, each word is represented by a vector determined during a neural network-based pre-training. The neural network determines the meaning of a word by considering a specified number of neighboring words. Therefore, the main advantage of word embeddings over LDA is that word embeddings consider the order of words when determining the meaning of a word. ${ }^{47}$ To obtain similarities, we calculate the documents' average word vectors and determine their cosine similarities. The (untabulated) results based on word embeddings show that the increase in topic similarity is highly significant for both the management reports and notes, albeit weaker in magnitude. ${ }^{48}$

\footnotetext{
${ }^{46}$ We match without replacement and a caliper range of 0.01 over the common support area. As a result, we achieve covariate balance between the two samples for all matching variables.

${ }^{47}$ We use the Word2Vec module developed by Mikolov et al. (2013) and the pre-trained German word vectors from fastText (Grave et al. 2018), which were trained based on the German Wikipedia corpus and web data from the Common Crawl project.

${ }^{48}$ The small magnitude is because of the high baseline similarity of all documents, which is driven by the broad training corpora (German Wikipedia and the Common Crawl project). Hence, in terms of topics, narrative firm disclosures will all be related to a broader business category and thus show high similarity.
} 
Finally, we employ a different approach to capture structure similarity. Specifically, for each document, we determine the depth of the structure as the number of headlines per 100 words. Our alternative structure measure is the absolute difference between client firms $i$ 's and $j$ 's structure depths, multiplied by -1 so that higher values represent more similar structure depths. Although the measure is relatively crude, untabulated results show that the similarities based on structure depth increase significantly for management reports and notes.

\section{Conclusions}

In this paper, we document that the similarities in the wording, content, and structure of audited narrative disclosures in the financial report are higher between two client firms when they share an audit partner. Therefore, our study is the first to show that individual audit partners influence their clients' narrative disclosures. Additionally, our study is the first to provide insights for the cases when audit partners are highly involved in the preparation processes of their clients' narrative disclosures, that is, when clients lack expertise or incentives. Moreover, we shed light on the mechanisms of this influence using field evidence and find that audit partners seem to be thoroughly involved in the preparation processes of their clients' narrative disclosures. We also show that the influence of audit partners on their clients' narratives is substantially more pronounced than the influence of audit offices or firms. Finally, we find positive consequences of audit partners being highly involved in the preparation of narrative disclosures.

Our findings may be helpful for investors, because we show that the influence of audit partners is associated with the usefulness of narrative disclosures for valuation. Moreover, our results inform regulators about the potential consequences of increased auditor responsibility for narrative disclosures, which several jurisdictions have already done or are contemplating (e.g., SEC 2002; PCAOB 2004; IAASB 2018).

The availability of a large set of audited narrative disclosures from private and public firms and of audit partner identities in Germany provides a unique setting for our analysis. However, this setting is also an important caveat of our study because the findings may not extend beyond Germany or apply to settings with different levels of assurance for narrative disclosures. This concern is attenuated by the findings of DeFranco et al. (2020), who show that audit firms even influence unaudited narrative disclosures. Nevertheless, we believe that additional research on the role of individual audit partners in other institutional environments may yield fruitful insights. Therefore, our findings, by stressing the importance of the individual audit partner level, may provide a starting point for more research in the data-rich US setting, which offers individual audit partner data beginning in 2017. 


\section{Appendix}

Table 10 Variable descriptions

Variable Description

$\Delta$ ROA $t+1_{i, j}$

$\triangle$ SENTIMENT_FORWARD $t_{i, j}$

ACCRUAL_SIM, i,j

BOTH_BIG_4 $4_{i, j}$

BOTH_PUBLIC $\mathrm{i}_{\mathrm{i}, \mathrm{j}}$

BOTH_SMALL $i, j$

CONTENT_SIM $_{\mathrm{i}, \mathrm{j}}$

CONTENT_SIM_WEMBED $\mathrm{i}_{\mathrm{i}, \mathrm{j}}$

FORWARD_SHARE $\mathrm{i}, \mathrm{j}$

GROWTH_SIMILARITY $Y_{i, j}$

HIGH_INVOLVED_AUDITOR

LENGTH_SIMILARITY $_{i, j}$
Client firms $i$ and $j$ 's mean change in ROA from year $t$ to $t+1$.

Mean change in sentiment of the forward-looking sentences of client firm $i$ 's and $j$ 's management reports from year $t-1$ to $t$.

Absolute difference in client firms $i$ 's and $j$ 's total accruals, multiplied by minus one and standardized to a mean of zero and a standard deviation of one.

Indicator variable that equals one if client firms $i$ 's and $j$ 's auditors are Big 4 auditors, and zero otherwise.

Indicator variable that equals one if both client firms $i$ and $j$ are public firms, and zero otherwise.

Indicator variable that equals one if both client firms $i$ and $j$ have below-median total assets in a year, and zero otherwise.

Content similarity score, computed as the cosine similarity between the topic vectors of the documents of client firms $i$ and $j$, log-transformed and multiplied by 100 .

Content similarity score based on word embeddings, measured as the cosine of the angle between the mean word vectors of management reports or notes $i$ and $j$, log-transformed and multiplied by 100 (variable for additional tests reported in the Online Appendix).

Number of words in forward-looking sentences in a management report, divided by the number of all words in a management report.

Absolute difference between the revenue growth of client firm $i$ and the revenue growth of client firm $j$, measured as the change in total sales from year $\mathrm{t}-1$ to $\mathrm{t}$ scaled by total sales in $\mathrm{t}-1$, multiplied by minus one.

Indicator variable that equals one if a client firm pair has an above-median composite score in a year, and zero otherwise. We calculate the composite score as described in the following: First, we adjust the similarity scores by regressing the raw similarity scores of each similarity measure on the control variables from our main model, and include client firm $i$-by year and client firm $j$-by year fixed effects. Next, we calculate a client firm-year measure by taking a client firm's median similarity with all client firms that share the same audit partner in a year. Because we conduct the corresponding analyses on the client firm-pair level, we calculate the mean value of client firm $i$ 's and client firm $j$ 's median similarity. We follow this procedure for each of our similarity measures and thereby obtain three values for an audit partner's influence on a client firm-pair (i.e., for wording, content, and structure). To obtain one measure that combines the three dimensions, we create a composite score based on the mean rank of the three similarity measures in a year.

Absolute difference in the number of words of management reports or notes $i$ and $j$, multiplied by minus one. 
Table 10 (continued)

Variable Description

LEVERAGE_SIMILARITY $_{\mathrm{i}, \mathrm{j}}$

MISSP_SHARE $\mathrm{i}_{\mathrm{i}, \mathrm{j}}$

NON_BOILER_WORD_SIM $\mathrm{i}_{\mathrm{j}}$

NON_STICKY_WORD_SIM

REDUNDANT_SHARE $\mathrm{i}_{\mathrm{i}, \mathrm{j}}$

ROA_SIMILARITY ${ }_{i, j}$

SAME_ACCOUNTS $\mathrm{i}_{\mathrm{i}, \mathrm{j}}$

SAME_AUDITOR(Firm) $)_{i, j}$

SAME_AUDITOR(Office $)_{i, j}$

SAME_AUDITOR(Partner) $)_{i, j}$

SAME_INDUSTRY ${ }_{i, j}$

SAME_REGION $\mathrm{i}_{\mathrm{i}, \mathrm{j}}$

SIZE_SIMILARITY ${ }_{i, j}$

STICKY_SHARE $i, j$

STRUCTURE_SIM ${ }_{\mathrm{i}, \mathrm{j}}$
Absolute difference between the leverage of client firm $i$ and the leverage of client firm $j$, measured as total debt scaled by total assets, multiplied by minus one.

Number of misspelled words in a management report, divided by the number of all words in a management report.

Textual similarity score, computed as the cosine similarity between the inverse document frequency-weighted term frequency vectors of the non-boilerplate parts of the management reports of client firms $i$ and $j$, log-transformed and multiplied by 100 . We define sentences as boilerplate if they contain an eight-gram of words that occurs in at least 10 percent of the sample narratives in a year.

Textual similarity score, computed as the cosine similarity between the inverse document frequency-weighted term frequency vectors of the non-sticky parts of the management reports of client firms $i$ and $j$, log-transformed and multiplied by 100 . We define sentences as sticky if they contain an eight-gram of words that occurs in the prior year's document.

Number of words in sentences that contain eight-grams of words that occur at least twice in a management report, divided by the number of all words in a management report.

Absolute difference between the return on assets of client firm $i$ and the return on assets of client firm $j$, multiplied by minus one.

Indicator variable that equals one if the financial reports of client firms $i$ and $j$ are both on a consolidated basis or both on a single-entity basis, and zero otherwise.

Indicator variable that equals one if client firms $i$ and $j$ are audited by the same audit firm but not the same audit office or partner, and zero otherwise.

Indicator variable that equals one if client firms $i$ and $j$ are audited by the same audit office but not the same audit partner, and zero otherwise.

Indicator variable that equals one if client firms $i$ and $j$ are audited by the same audit partner, and zero otherwise.

Indicator variable that equals one if client firms $i$ and $j$ share the same two-digit SIC industry code, and zero otherwise.

Indicator variable that equals one if client firms $i$ and $j$ share the first two digits of the ZIP code, and zero otherwise.

Difference between the natural logarithm of total assets of client firm $i$ and the natural logarithm of total assets of client firm $j$, multiplied by minus one.

Number of words in sentences that contain eight-grams of words that are repeated from the prior year's management report, divided by the number of all words in a management report.

Structure similarity score, computed as the cosine similarity between the headline vectors of client firms $i$ and $j$, log-transformed and multiplied by 100 . 
Table 10 (continued)

\begin{tabular}{|c|c|}
\hline Variable & Description \\
\hline STRUCTURE_SIM_DEPTH $_{\mathrm{i}, \mathrm{j}}$ & $\begin{array}{l}\text { Structure similarity score, measured as the absolute difference in } \\
\text { the number of headlines per } 100 \text { words of management reports } \\
\text { or notes } i \text { and } j \text {, multiplied by minus one, converted with a } \\
\text { positive translation by the minimum value, log-transformed and } \\
\text { multiplied by } 100 \text {. (variable for additional tests reported in the } \\
\text { Online Appendix). }\end{array}$ \\
\hline WEBSITE_SIM $_{\mathrm{i}, \mathrm{j}}$ & $\begin{array}{l}\text { Textual similarity score, computed as the cosine of the angle } \\
\text { between the IDF-weighted term frequency vectors of the website } \\
\text { text of client firms } i \text { and } j, \log \text {-transformed and multiplied by } 100 \\
\text { (variable for additional tests reported in the Online Appendix). }\end{array}$ \\
\hline WORDING_SIM $_{\mathrm{i}, \mathrm{j}}$ & $\begin{array}{l}\text { Textual similarity score, computed as the cosine similarity } \\
\text { between the inverse document frequency-weighted term fre- } \\
\text { quency vectors of the management reports or notes of client } \\
\text { firms } i \text { and } j, \log \text {-transformed and multiplied by } 100 \text {. }\end{array}$ \\
\hline WORDING_SIM_WCF ${ }_{i, j}$ & $\begin{array}{l}\text { Textual similarity score, measured as the percentage of text } \\
\text { that appears in both management reports or notes } i \text { and } j \text {, } \\
\text { measured by the text reuse-detection software WCopyFind, log- } \\
\text { transformed and multiplied by } 100 \text { (variable for additional tests } \\
\text { reported in the Online Appendix). }\end{array}$ \\
\hline
\end{tabular}

Table 11 Examples of textual similarity from risk disclosures

\section{Panel A: Example with WORDING_SIM = 16.7 percent}

Excerpt from the 2012 management report of Valsabbia Deutschland GmbH

\section{Risikobericht}

\section{Allgemeiner Risikobericht:}

Potenzielle Risiken, die die Vermögens-, Finanzund Ertragslage der Gesellschaft beeinflussen könnten bestehen nicht. Dem Wettbewerb am Markt werden wir weiterhin durch unsere Erfahrung, Innovation und Zuverlässigkeit begegnen.

\section{Spezieller Risikobericht:}

Die Liquiditätslage ist sehr zufriedenstellend; es sind keine Engpässe $\mathrm{zu}$ erwarten. $\mathrm{Zu}$ den im Unternehmen bestehenden Finanzinstrumenten zählen im wesentlichen Forderungen, Verbindlichkeiten und Guthaben bei Kreditinstituten. Verbindlichkeiten werden innerhalb der vereinbarten Zahlungsfristen gezahlt. Es bestehen keine bestandsgefährdenden Risiken.
Excerpt from the 2012 management report of MEYER-JUMBO Logistics GmbH \& Co. KG

\section{CHANCEN UND RISIKOBERICHT}

\section{Risikobericht}

Die Liquiditätslage ist zufriedenstellend; es sind keine Engpässe zu erwarten. Das Unternehmen verfügt über einen solventen Kundenstamm, Forderungsausfälle sind die Ausnahme. Um dieses Risiko, vor allem in Verbindung mit Neukunden weitestgehend auszuschließen, haben wir in 2012 eine Warenkreditversicherung abgeschlossen. Verbindlichkeiten werden innerhalb der vereinbarten Zahlungsziele gezahlt. Längerfristige Finanzierungen erfolgen nur im Bereich des Anlagevermögens. Im kurzfristigen Bereich finanziert sich das Unternehmen überwiegend über Bankkreditlinien, Lieferantenkredite und Zahlungsvereinbarungen mit nahestehenden Unternehmen der Firmengruppe. Grundstücke und Gebäude sowie der Fuhrpark sind von Gesellschaftern und nahestehenden Unternehmen angemietet/angepachtet. Deshalb sehen wir zusammenfassend keine größeren Risiken hinsichtlich der zukünftigen Entwicklung, zumal, da die EURO-Krise ja zumindest mittelfristig enden wird. 
Table 11 (continued)

Panel B: Example with WORDING_SIM = 69.2 percent

Excerpt from the 2012 management report of Rosner Holding GmbH

VI. Risikoberichterstattung über die Verwendung von Finanzinstrumenten

Zu den in der Unternehmensgruppe bestehenden Finanzinstrumenten zählen im Wesentlichen Forderungen, Verbindlichkeiten und Guthaben bei Kreditinstituten. Die Gesellschaften verfügen über einen solventen Kundenstamm. Forderungsausfälle sind die absolute Ausnahme. Zudem besteht eine langjährige Zusammenarbeit mit einem Großteil der Kunden. Verbindlichkeiten werden stets innerhalb der vereinbarten Zahlungsfristen gezahlt. Im kurzfristigen Bereich finanzieren sich unsere Unternehmen zum Teil mittels Lieferantenkrediten. Zugesagte Kreditlinien verschiedener Banken werden nicht in Anspruch genommen. Ziel des Finanz- und Risikomanagements der Gesellschaften ist die Sicherung des Unternehmenserfolgs gegen finanzielle Risiken jeglicher Art. Beim Management der Finanzpositionen verfolgen die Unternehmen eine konservative Risikopolitik. Soweit bei finanziellen Vermögenswerten Ausfall- und Bonitätsrisiken erkennbar sind, werden entsprechende Wertberichtigungen vorgenommen. Zur Minimierung von Ausfallrisiken verfügen die Unternehmen über ein adäquates Debitorenmanagement. Warenkreditversicherungen bestehen nicht. Vor Eingehung neuer Geschäftsbeziehung werden stets Auskünfte über die Bonität der Kunden eingeholt.
Excerpt from the 2012 management report of $\mathrm{W}+\mathrm{W}$ Verwaltungsgesellschaft $\mathrm{mbH}$

VI. Risikoberichterstattung über die Verwendung von Finanzinstrumenten

Zu den im Konzern bestehenden Finanzinstrumenten zählen im Wesentlichen Forderungen, Verbindlichkeiten und Guthaben bei Kreditinstituten. Die Unternehmensgruppe verfügt über einen solventen Kundenstamm, Forderungsausfälle sind die Ausnahme. Zudem besteht eine langjährige Zusammenarbeit mit dem Großteil der Kunden. Verbindlichkeiten werden innerhalb der vereinbarten Zahlungsfristen gezahlt. Im kurzfristigen Bereich finanziert sich der Konzern überwiegend über die Inanspruchnahme der Kreditlinien der Banken. Ziel des Finanz- und Risikomanagements ist die Sicherung des Konzernerfolgs gegen finanzielle Risiken jeglicher Art. Beim Management der Finanzpositionen verfolgt der Konzern eine konservative Risikopolitik. Zur Absicherung gegen das Liquiditätsrisiko wird eine Liquiditätsplanung fortlaufend geführt, die einen Überblick über die Geldausund - eingänge vermittelt. Soweit bei finanziellen Vermögenswerten Ausfallund Bonitätsrisiken erkennbar sind, werden entsprechende Wertberichtigungen vorgenommen. Zur Minimierung von Ausfallrisiken verfügt der Konzern über ein adäquates Debitorenmanagement. Zudem werden vor Eingehung neuer Geschäftsbeziehungen stets Informationen über die Bonität der Geschäftspartner eingeholt.

This table presents two pairs of excerpts from management reports with two different similarity values. For visualization purposes, similar parts are in italics with diverging wording in bold. The similarity scores of the excerpts are not comparable to the similarity of the whole documents 
Table 12 Client firm-year descriptive statistics

\begin{tabular}{|c|c|c|c|c|c|c|}
\hline & $\mathrm{N}$ & Mean & STD & Q1 & Median & Q3 \\
\hline TOTAL_ASSETS & 6238 & 154288.588 & 231017.065 & 27934.283 & 58723.517 & 155179.157 \\
\hline REVENUE $_{\mathrm{i}}$ & 6238 & 296737.369 & 674277.683 & 43180.520 & 85522.081 & 215239.000 \\
\hline EMPLOYEES $_{\mathrm{i}}$ & 6238 & 1279.678 & 2669.580 & 162.000 & 393.000 & 1011.000 \\
\hline ACCRUALS $_{\mathrm{i}}$ & 4480 & -0.049 & 0.124 & -0.098 & -0.043 & 0.005 \\
\hline $\mathrm{ROA}_{\mathrm{i}}$ & 6238 & 7.105 & 9.087 & 2.230 & 5.940 & 10.990 \\
\hline LEVERAGE $_{\mathrm{i}}$ & 6238 & 4.544 & 15.348 & 0.950 & 1.780 & 3.330 \\
\hline CONSOLIDATED $_{i}$ & 6238 & 0.667 & 0.471 & 0.000 & 1.000 & 1.000 \\
\hline PUBLIC $_{i}$ & 6238 & 0.103 & 0.303 & 0.000 & 0.000 & 0.000 \\
\hline BIG_ $4_{i}$ & 6238 & 0.261 & 0.439 & 0.000 & 0.000 & 1.000 \\
\hline
\end{tabular}

This table presents descriptive statistics on the client firm-year level. TOTALASSETS $S_{i}$ is total assets in thousand euros of client firm i. REVENUE $E_{i}$ is the net sales in thousand euros of client firm i. EMPLOYEES is the number of employees in thousands of client firm i. ACCRUALS $S_{i}$ is net income less operating cash flow in thousand euros of client firm $i$, scaled by total assets in t-1. $R O A_{i}$ is the return on assets of client firm $i$, calculated as net income divided by total assets. $L E V E R A G E_{i}$ is the financial leverage of client firm $i$, calculated as book-value of debt divided by book-value of equity. CONSOLIDATED $D_{i}$ is an indicator variable that equals one if the financial reports of client firm $i$ are on a consolidated basis, and zero if on a single-entity basis. $P U B L I C_{i}$ is an indicator variable that equals one if client firm $i$ is a publicly listed firm, and zero if it is a private firm. $B_{-} G_{-} 4_{i}$ is an indicator variable that equals one if client firm $i$ has a Big 4 auditor, and zero if it has a non-Big 4 auditor

Supplementary Information The online version contains supplementary material available at https://doi.org/10.1007/s11142-021-09634-4.

Acknowledgements The authors would like to thank Stephen Brown, Jeff Zeyun Chen, Claire Estebanez (discussant), Ties de Kok, Beatriz García Osma, Wayne Guay, Alexander Hillert, Katharina Hombach (discussant), Peter Kajüter, Russel Lundholm (editor), Christian Leuz, Maximilian Muhn, Phil Quinn, Anna Rohlfing-Bastian, Julia Schneider (discussant), Ann Vanstraelen, Steven Young, an anonymous referee and participants at AAA Annual Meeting 2018, Graz DART Workshop 2019, Mannheim Empirical Accounting and Finance Workshop 2019, 35th EAA Doctoral Colloquium \& EAA Annual Congress 2019, GEABA XX. Symposium 2019, BFGA Conference 2019, and workshop participants at University of Mannheim and University of Washington for their helpful comments and suggestions. We also sincerely thank the audit partners who voluntarily participated in our interview study. All remaining errors are ours. Part of this research was conducted while Christoph Mauritz was visiting at University of Washington. Martin Nienhaus acknowledges financial support by the German Research Foundation (DFG Project 395387084)

Funding Open Access funding enabled and organized by Projekt DEAL.

Open Access This article is licensed under a Creative Commons Attribution 4.0 International License, which permits use, sharing, adaptation, distribution and reproduction in any medium or format, as long as you give appropriate credit to the original author(s) and the source, provide a link to the Creative Commons licence, and indicate if changes were made. The images or other third party material in this article are included in the article's Creative Commons licence, unless indicated otherwise in a credit line to the material. If material is not included in the article's Creative Commons licence and your intended use is not permitted by statutory regulation or exceeds the permitted use, you will need to obtain permission directly from the copyright holder. To view a copy of this licence, visit http://creativecommons.org/licenses/by/4.0/. 


\section{References}

Ball, R., A. Robin, and J.S. Wu. 2003. Incentives versus standards: Properties of accounting income in four east asian countries. Journal of Accounting and Economics 36: 235-270.

Barron, O.E., C.O. Kile, and T.B. O'Keefe. 1999. MD\&A quality as measured by the SEC and analysts' earnings forecasts. Contemporary Accounting Research 16: 75-109.

Beattie, V. 2014. Accounting narratives and the narrative turn in accounting research: Issues, theory, methodology, methods and a research framework. The British Accounting Review 46: 111-134.

Beattie, V., S. Fearnley, and R. Brandt. 2004. A grounded theory model of auditor-client negotiations. International Journal of Auditing 8: 1-19.

Becker, C.L., M.L. DeFond, J. Jiambalvo, and K.R. Subramanyam. 1998. The effect of audit quality on earnings management. Contemporary Accounting Research 15: 1-24.

Bedard, J.C., D.R. Deis, M.B. Curtis, and J.G. Jenkins. 2008. Risk monitoring and control in audit firms: A research synthesis. Auditing: A Journal of Practice \& Theory 27: 187-218.

Bell, T.B., M. Causholli, and W.R. Knechel. 2015. Audit firm tenure, non-audit services, and internal assessments of audit quality. Journal of Accounting Research 53: 461-509.

Bertrand, M., and A. Schoar. 2003. Managing with style: The effect of managers on firm policies. The Quarterly Journal of Economics 118: 1169-1208.

Blei, D.M., A.Y. Ng, and M.I. Jordan. 2003. Latent Dirichlet allocation. Journal of Machine Learning Research 3: 993-1022.

Bloomfield, R., M.W. Nelson, and E. Soltes. 2016. Gathering data for archival, field, survey, and experimental accounting research. Journal of Accounting Research 54: 341-395.

Brown, S.V., and W.R. Knechel. 2016. Auditor-client compatibility and audit firm selection. Journal of Accounting Research 54: 725-775.

Brown, S.V., and J.W. Tucker. 2011. Large-sample evidence on firms' year-over-year MD\&A modifications. Journal of Accounting Research 49: 309-346.

Bryan, S.H. 1997. Incremental information content of required disclosures contained in management discussion and analysis. The Accounting Review 72: 285-301.

Burke, J.J., R. Hoitash, and U. Hoitash. 2019. Audit partner identification and characteristics: Evidence from U.S. form AP filings. Auditing: A Journal of Practice \& Theory 38: 71-94.

Carcello, J.V., and C. Li. 2013. Costs and benefits of requiring an engagement partner signature: Recent experience in the United Kingdom. The Accounting Review 88: 1511-1546.

Carey, P., and R. Simnett. 2006. Audit partner tenure and audit quality. The Accounting Review 81: 653676.

Chen, C.-Y., C.-J. Lin, and Y.-C. Lin. 2008. Audit partner tenure, audit firm tenure, and discretionary accruals: Does long auditor tenure impair earnings quality? Contemporary Accounting Research 25 : $415-445$.

Chen, J.Z., M.-H. Chen, C.-L. Chin, and G.J. Lobo. 2020. Do firms that have a common signing auditor exhibit higher earnings comparability? The Accounting Review 95: 115-143.

Chen, S., S.Y.J. Sun, and D. Wu. 2010. Client importance, institutional improvements, and audit quality in China: An office and individual auditor level analysis. The Accounting Review 85: 127-158.

Church, B.K., S.M. Davis, and S.A. McCracken. 2008. The auditor's reporting model: A literature overview and research synthesis. Accounting Horizons 22: 69-90.

Clarkson, P.M., J.L. Kao, and G.D. Richardson. 1999. Evidence that management discussion and analysis (MD\&A) is a part of a firm's overall disclosure package. Contemporary Accounting Research 16: 111-134.

DeFond, M.L., and J.R. Francis. 2005. Audit research after Sarbanes-Oxley. Auditing: A Journal of Practice \& Theory 24: 5-30.

DeFranco, G., H. Fogel-Yaari, and H. Li. 2020. MD\&A textual similarity and auditors. Auditing: A Journal of Practice \& Theory 39: 105-131.

DeFranco, G., S.P. Kothari, and R.S. Verdi. 2011a. The benefits of financial statement comparability. Journal of Accounting Research 49: 895-931.

DeFranco, G., M.F. Wong, and Y. Zhou. 2011b. Accounting adjustments and the valuation of financial statement note information in 10-k filings. The Accounting Review 86: 1577-1604.

Dunn, K.A., and B.W. Mayhew. 2004. Audit firm industry specialization and client disclosure quality. Review of Accounting Studies 9: 35-58. 
Dyer, T., M. Lang, and L. Stice-Lawrence. 2017. The evolution of 10-K textual disclosure: Evidence from Latent Dirichlet Allocation. Journal of Accounting and Economics 64: 221-245.

Fee, C.E., C.J. Hadlock, and J.R. Pierce. 2013. Managers with and without style: Evidence using exogenous variation. The Review of Financial Studies 26: 567-601.

Francis, J.R. 2011. A framework for understanding and researching audit quality. Auditing: A Journal of Practice \& Theory 30: 125-152.

Francis, J.R., M.L. Pinnuck, and O. Watanabe. 2014. Auditor style and financial statement comparability. The Accounting Review 89: 605-633.

Francis, J., K. Schipper, and L. Vincent. 2003. The relative and incremental explanatory power of earnings and alternative (to earnings) performance measures for returns. Contemporary Accounting Research 20: $121-164$.

Ge, W., D. Matsumoto, and J.L. Zhang. 2011. Do CFOs have style? An empirical investigation of the effect of individual CFOs on accounting practices. Contemporary Accounting Research 28: 1141-1179.

Grave, E., P. Bojanowski, P. Gupta, A. Joulin, and T. Mikolov. 2018. Learning word vectors for 157 languages. Proceedings of the Eleventh International Conference on Language Resources and Evaluation (LREC 2018).

Gul, F.A., D. Wu, and Z. Yang. 2013. Do individual auditors affect audit quality? Evidence from archival data. The Accounting Review 88: 1993-2023.

Guy, B.S., and W.E. Patton. 1988. The marketing of altruistic causes: Understanding why people help. Journal of Services Marketing 2: 5-16.

Hanley, K.W., and G. Hoberg. 2010. The information content of IPO prospectuses. Review of Financial Studies 23: 2821-2864.

Höfer, J. 2016. Determinanten der Zukunftsorientierung in der Berichterstattung deutscher Aktiengesellschaften: Eine panelökonometrische Untersuchung der HDAX-Unternehmen von 2003 bis 2012. Rainer Hampp Verlag: Mering.

Hoorens, V. 1993. Self-enhancement and superiority biases in social comparison. European Review of Social Psychology 4: 113-139.

IAASB. 2018. Supporting credibility and trust in emerging forms of external reporting: Ten key challanges for assurance engagements. https://www.ifac.org/system/files/publications/files/ IAASB-EER-Feedback-Statement_0.pdf. Accessed 1 July 2021.

Jenkins, J.G., D.R. Deis, J.C. Bedard, and M.B. Curtis. 2008. Accounting firm culture and governance: A research synthesis. Behavioral Research in Accounting 20: 45-74.

Jeppesen, K.K. 2007. Organizational risk in large audit firms. Managerial Auditing Journal 22: 590-603.

Knechel, W.R., A. Vanstraelen, and M. Zerni. 2015. Does the identity of engagement partners matter? An analysis of audit partner reporting decisions. Contemporary Accounting Research 32: 1443-1478.

Leuz, C., D. Nanda, and P.D. Wysocki. 2003. Earnings management and investor protection: An international comparison. Journal of Financial Economics 69: 505-527.

Li, F. 2010. The information content of forward-looking statements in corporate filings - a naïve bayesian machine learning approach. Journal of Accounting Research 48: 1049-1102.

Li, F., R. Lundholm, and M. Minnis. 2013. A measure of competition based on 10-k filings. Journal of Accounting Research 51: 399-436.

López, A. 2014. Outsourcing and firm productivity: A production function approach. Empirical Economics 47: 977-998.

Max-Neef, M.A. 1991. Human scale development: Conception application and further reflections. New York: Apex Press.

McMullin, J.L. 2016. Can I borrow your footnotes? Footnote boilerplate's learning externality. Working paper.

Mikolov, T., K. Chen, G. Corrado, and J. Dean. 2013. Efficient estimation of word representations in vector space. Proceedings of the International Conference on Learning Representations (ICLR 2013).

Nelson, M.W., and H.-T. Tan. 2005. Judgment and decision making research in auditing: A task, person, and interpersonal interaction perspective. Auditing: A Journal of Practice \& Theory 24: 41-71.

PCAOB. 2004. Standing advisory group meeting, June 21-22, 2004: Potential project - auditor's responsibility for communications to investors containing financial information. https:/pcaobus.org/News/ Events/Documents/06212004\SAGMeeting/Agenda\%20item\%208.pdf. Accessed 1 July 2021.

PCAOB. 2015. Improving the transparency of audits: Rules to require disclosure of certain audit participants on a new PCAOB form and related amendments to auditing standards. https://pcaobus.org/ Rulemaking/Docket029/Release-2015-008.pdf. Accessed 1 July 2021. 
Reichelt, K.J., and D. Wang. 2010. National and office-specific measures of auditor industry expertise and effects on audit quality. Journal of Accounting Research 48: 647-686.

Remus, R., U. Quasthoff, and G. Heyer. 2010. SentiWS - a publicly available German-language resource for sentiment analysis. Proceedings of the 7th International Language Ressources and Evaluation (LREC 2010).

Reynolds, J., and J.R. Francis. 2000. Does size matter? The influence of large clients on office-level auditor reporting decisions. Journal of Accounting and Economics 30: 375-400.

Salton, G., A. Wong, and C.S. Yang. 1975. A vector space model for automatic indexing. Communications of the ACM 18: 613-620.

SEC. 2002. Proposed rule: Disclosure in management's discussion and analysis about the application of critical accounting policies. https://www.sec.gov/rules/proposed/33-8098.htm. Accessed 1 July 2021.

Zerni, M. 2012. Audit partner specialization and audit fees: Some evidence from Sweden. Contemporary Accounting Research 29: 312-340.

Publisher's note Springer Nature remains neutral with regard to jurisdictional claims in published maps and institutional affiliations. 